\title{
Maize Transformation: From Plant Material to the Release of Genetically Modified and Edited Varieties
}

\section{OPEN ACCESS}

Edited by:

Horacio Esteban Hopp,

University of Buenos Aires, Argentina

Reviewed by:

Cecilia Decima Oneto, Instituto Nacional de Tecnología

Agropecuaria, Argentina

Hugo Raúl Permingeat, National University of Rosario, Argentina

${ }^{*}$ Correspondence: Paulo Arruda parruda@unicamp.br Juliana Erika de Carvalho

Teixeira Yassitepe

juliana.yassitepe@embrapa.br

Specialty section:

This article was submitted to Technical Advances in Plant Science,

a section of the journal

Frontiers in Plant Science

Received: 29 August 2021 Accepted: 15 September 2021

Published: 14 October 2021

Citation:

Yassitepe JECT, da Silva VCH, Hernandes-Lopes J, Dante RA, Gerhardt IR, Fernandes FR, Silva PA,

Vieira $L R$, Bonatti $V$ and

Arruda P (2021) Maize

Transformation: From Plant Material to the Release of Genetically Modified and Edited Varieties.

Front. Plant Sci. 12:766702. doi: 10.3389/fpls.2021.766702

\begin{abstract}
Juliana Erika de Carvalho Teixeira Yassitepe ${ }^{1,2,3 *}$, Viviane Cristina Heinzen da Silva ${ }^{2,3}$, José Hernandes-Lopes ${ }^{1,2,3}$, Ricardo Augusto Dante ${ }^{1,2,3}$, Isabel Rodrigues Gerhardt t,2,3, Fernanda Rausch Fernandes ${ }^{1,2,3}$, Priscila Alves da Silva ${ }^{2,3}$, Leticia Rios Vieira ${ }^{2,3}$, Vanessa Bonatti $i^{2,3}$ and Paulo Arruda ${ }^{2,3,4 *}$

'Embrapa Informática Agropecuária, Campinas, Brazil, ${ }^{2}$ Genomics for Climate Change Research Center (GCCRC), Universidade Estadual de Campinas, Campinas, Brazil, ${ }^{3}$ Centro de Biologia Molecular e Engenharia Genética, Universidade Estadual de Campinas, Campinas, Brazil, ${ }^{4}$ Departamento de Genética, Evolução, Microbiologia e Imunologia, Instituto de Biologia, Universidade Estadual de Campinas, Campinas, Brazil
\end{abstract}

Over the past decades, advances in plant biotechnology have allowed the development of genetically modified maize varieties that have significantly impacted agricultural management and improved the grain yield worldwide. To date, genetically modified varieties represent $30 \%$ of the world's maize cultivated area and incorporate traits such as herbicide, insect and disease resistance, abiotic stress tolerance, high yield, and improved nutritional quality. Maize transformation, which is a prerequisite for genetically modified maize development, is no longer a major bottleneck. Protocols using morphogenic regulators have evolved significantly towards increasing transformation frequency and genotype independence. Emerging technologies using either stable or transient expression and tissue culture-independent methods, such as direct genome editing using RNA-guided endonuclease system as an in vivo desired-target mutator, simultaneous double haploid production and editing/haploid-inducer-mediated genome editing, and pollen transformation, are expected to lead significant progress in maize biotechnology. This review summarises the significant advances in maize transformation protocols, technologies, and applications and discusses the current status, including a pipeline for trait development and regulatory issues related to current and future genetically modified and genetically edited maize varieties.

Keywords: maize, plant transformation, gene editing, plant biotechnology, genetic modification, morphogenic regulator-mediated transformation

\section{INTRODUCTION}

As an important global crop and a model plant for genetics and biotechnology studies, maize is one of the most researched plant species. Because of its richness in genetic and genomic resources, maize has been used for biological investigations into plant domestication and evolution, epigenetics, heterosis, disease, insect resistance inheritance, doubled haploids, genome editing, and breeding tools (Strable and Scanlon, 2009; Andorf et al., 2019). However, the 
development of genetically modified maize varieties has faced enormous difficulties due to genotype-associated recalcitrance to transformation. The first protocols for stable maize transformation, which were published in the late 1980s, used particle bombardment, but the transformation frequency obtained with the method was very low (Gordon-Kamm et al., 1990; Frame et al., 1994). Nevertheless, agricultural biotechnology companies were able to launch commercial transgenic varieties using this protocol (ISAAA database, 2021). A few years later, the overwhelming success of herbicide- and insect-resistant transgenic maize varieties modified the global seed industry from a pulverized market with several local and small seed companies into a consolidated market with a few transnational companies able to invest in research and bear the expensive regulatory costs to commercialize genetically modified varieties (Bijman, 2001; Howard, 2009). In 2019, genetically modified maize varieties accounted for over $30 \%$ of the world's maize cultivated area (ISAAA database, 2021). The list of the so-called biotech traits currently available is no longer restricted to herbicide and insect resistance; abiotic stress tolerance, high yield, and improved nutritional quality are traits expected to be introduced into the market soon (Wu et al., 2019; Simmons et al., 2020; ISAAA database, 2021).

The progress in maize transformation protocols over the years aimed to overcome genotype recalcitrance and produce less complex and unfragmented transgene insertions in the plant genome, which is a major drawback associated with the regulatory aspects of transgenics (Kausch et al., 2021a). As a result, Agrobacterium-mediated transformation has become the most suitable protocol for selecting single and unfragmented insertion events. Increasing the transformation frequency and expanding the number of genotypes suitable for Agrobacterium infection and plant regeneration of transgenic events were the focus of research groups in both the industrial and academic sectors (Frame et al., 2002, 2006; Ishida et al., 2003, 2007; Huang and Wei, 2005; Lowe et al., 2018). In parallel to improvements in protocols for Agrobacterium infection and transformation, advances have also been achieved in plasmid design, suitable promoters, and selectable marker genes (Kausch et al., 2021b; Simmons et al., 2021). One of the most significant advances that resulted in improvements in maize transformation was the design of constructs expressing morphogenetic regulators (MRs) that allow direct embryogenesis from immature zygotic embryos (IZEs) and thereby bypass the callus induction stage (Lowe et al., 2016, 2018; Svitashev et al., 2016; Mookkan et al., 2017; Barone et al., 2020). For example, vector constructs expressing the MRs BABY BOOM and WUSCHEL allowed the transformation of elite maize inbred lines at frequencies of up to $50 \%$, and this process bypasses the laborious and time-consuming backcross programmes for introgression of the transgene into commercial hybrids (Lowe et al., 2016).

The costs associated with the deregulation of genetically modified commercial maize plants are prohibitive for most public research institutions. Only the largest agricultural biotechnology companies are financially prepared to pay these costs, and therefore, the world has seen an increasing concentration of maize seed providers (Deconinck, 2019). This scenario may be overcome by gene-editing technologies that simplify gene structure/expression manipulation (Jorasch, 2020). Provided that regulatory agencies worldwide become aware of the potential of extensively using this technology, gene editing will soon become more accessible to the public interested in contributing to agricultural sustainability, which will allow the worldwide development of biotechnology varieties that incorporate desirable traits (Schiemann et al., 2019). Geneediting technologies will also benefit from the progress being made in DNA and protein delivery mechanisms and tissue culture-free methods for maize modification (Li et al., 2017; Vejlupkova et al., 2020). For example, double haploid induction associated with gene editing methods [simultaneous double haploid production and editing (Hi-Edit) and haploid-inducer mediated genome editing (IMGE)] opens new opportunities to speed up precision breeding (Kelliher et al., 2019; Wang et al., 2019). The possibility of obtaining genetically modified plants without integrating foreign DNA also opens a new path for the deregulation of biotech traits. In several countries, including Argentina, Brazil, and the USA, genome-edited varieties that do not incorporate foreign DNA have already been deregulated as conventional improved varieties with no additional restrictions (Hull et al., 2021). The potential lack of a need for approval by regulatory agencies would significantly reduce the time and costs to introducing the new edited varieties to the market compared with those needed for regulated transgenic varieties (Lassoued et al., 2019).

Recent advances in the transformation and regulatory aspects of genetically modified/edited maize plants have encouraged academic and private facilities to provide transformation services, which has allowed small research groups and companies to test their genes and alleles. In addition, the genome sequences of several maize lines and hybrids are already available (Hufford et al., 2021), which allows the design of strategies for genetic modification/edition using improved transformation protocols. These improvements will allow the evaluation of an increasing number of genes and alleles associated with desirable agronomic traits (Portwood et al., 2019).

As a critical technology, maize transformation has been the central theme of several reviews covering different aspects ranging from historical and current advances in transformation protocols, methods, and applications (Wang et al., 2009; Que et al., 2014; Yadava et al., 2017; Ishida et al., 2020; Kausch et al., 2021a, 2021b). Here, we present the latest advances in the protocols and technologies for maize transformation and expand the topic to the development of new genetically engineered maize varieties, regulatory issues, and the importance of delivering new commercial biotech maize varieties to the market.

\section{CURRENT STATUS OF MAIZE TRANSFORMATION}

\section{Plant Genotype}

One of the bottlenecks associated with Agrobacterium-mediated transformation is the recalcitrance of maize to bacterial infection and the regeneration of transformed plants. Almost all published 
protocols have yielded the successful transformation of a few genotypes that usually exhibit satisfactory Agrobacterium infection, callus formation, and plant regeneration (Ishida et al., 1996, 2003; Frame et al., 2006; Coussens et al., 2012). The most commonly used maize genotype in academic laboratories is the single hybrid Hi-II (Armstrong et al., 1991) and their inbred parents (Frame et al., 2006; Ishida et al., 2007). However, although these genotypes show high-frequency Agrobacterium infection of IZEs, embryogenic callus formation, good performance in selective medium, and recovery of transformed plants, they lack the minimal agronomic performance needed for phenotyping characterization (Frame et al., 2006; Wang et al., 2009; Kausch et al., 2021a). In addition, events generated from individual embryos produced by self-pollinated Hi-II hybrid plants have different genetic backgrounds. These constraints require time-consuming backcross programmes for the introgression of transgenic events into elite inbred lines for phenotypic evaluation. More recently, the B104 maize inbred line has been used for maize transformation. Although this genotype presents a slightly lower transformation frequency, the plants have better agronomic performance, which allows phenotyping of the transformed plants at the $T_{1}$ generation. In general, the transformed B104 plants are vigorous and produce a high number of kernels in the $\mathrm{T}_{1}$ generation, which allows the selection of homozygous transformed alleles when self-pollinated (Frame et al., 2006; Coussens et al., 2012; Raji et al., 2018). The B104 maize inbred line, when crossed with elite lines, gives rise to single hybrids that show suitable yield performance in field trials (Feys et al., 2018). Companies usually utilize their proprietary elite genotypes, such as NP2222 (Zhong et al., 2018), PHR03, PH184C, and PH1V69 (Simmons et al., 2021). Tropical maize genotypes have also been transformed (Yadava et al., 2017). In general, the transformation efficiency was lower than that of the temperate genotypes with the exception of that reported for the Sudanese inbred line IL3, which reached $3.78 \%$ compared with $0.98 \%$ of the A188 inbred line (Omer et al., 2013).

\section{Explant Material}

Genetic transformation requires the efficient introduction of a DNA construct harbouring target and marker genes into the plant cell, which is an effective tissue culture and plant regeneration protocol that allows selection of the transformed cell/tissue, and the further development of fertile plants. The first maize transformation protocols used cell suspensions and calli as explants, and the DNA construct was delivered by particle bombardment (Gordon-Kamm et al., 1990). A few years later, successful maize transformation was achieved using Agrobacterium tumefaciens carrying a modified bacteria $\mathrm{Ti}$ plasmid harbouring a gene conferring antibiotic resistance (Ishida et al., 1996). Nevertheless, the transformation frequency achieved with either particle bombardment or Agrobacterium was very low. In the following years, the construct design was improved to incorporate high-expression promoters to drive selectable marker and target gene expression, which, along with improvements in the culture media and infection treatments, increased the proportion of single-copy insertion events and made Agrobacterium the best choice for maize transformation (Frame et al., 2002; Kausch et al., 2021b). In general, the improved protocols made use of the highly efficient Agrobacterium strains EHA101 (Hood et al., 1986), EHA105 (Du et al., 2019), and LBA4404 (Ishida et al., 1996, 2007; Zhong et al., 2018). Although attempts have been made to use different explants (Mu et al., 2012), almost all current protocols use IZEs for Agrobacterium-mediated transformation due to the wellestablished callus induction and somatic embryogenesis obtained with this explant (Wang et al., 2009; Yadava et al., 2017; Kausch et al., 2021b). IZEs give rise to type II callus-induced somatic embryos that, upon efficient selection, produce regenerated transformed events (Kausch et al., 2021a).

Although IZEs are the best explant choice for maize transformation, care should be taken regarding aspects that affect transformation frequency. First, maize plants must be grown in a greenhouse with environmental control to ensure the homogeneous growth of healthy and vigorous plants, particularly for routine transformation throughout the year (Ishida et al., 2020). Detailed protocols for growing maize in greenhouses are available in the literature (Eddy and Hahn, 2012), but adjustments to the temperature, light quality/intensity, optimized nutritional conditions, and disease controls are often needed to ensure the quality of IZE production. Second, for classical Agrobacterium-mediated transformation, fresh embryos varying in size between $1.2 \mathrm{~mm}$ and $2 \mathrm{~mm}$ should be used (Raji et al., 2018). It is important to note that the embryo size usually varies within a single ear, and very small or larger embryos thus need to be discarded.

\section{Culture Media}

In general, maize transformation protocols use culture media prepared with N6 or MS salts (Frame et al., 2006). The protocols can be optimized by altering the combinations of sugars, salts, vitamins, amino acids, antioxidants, antibiotics, and growth regulators (Ishida et al., 2003; Frame et al., 2006; Yadava et al., 2017). Supplementation with silver nitrate has resulted in increased embryogenic callus induction and the recovery of regenerated plants (Ishida et al., 2003; Wang et al., 2009). The combination of copper sulfate $\left(\mathrm{CuSO}_{4}\right)$ with 6-benzyl amino purine (BAP) has been shown to increase embryogenic callus induction and plant regeneration (Cho et al., 2014), whereas the combination of BAP with cysteine and dithiothreitol increases the infection rate (Du et al., 2010). Factors influencing Agrobacterium-mediated transformation include the concentration of the virulence inducer acetosyringone, the cocultivation time, and preinoculum bacterial growth (Du et al., 2019).

The effective concentrations of selective agents (antibiotics, herbicides, and sugars) should be optimized to inhibit the growth of nontransformed cell clusters (Wang et al., 2009; Que et al., 2014; Dong et al., 2021). In addition, nontransformed callus sectors that commonly grow around the transformed cell clusters should be removed to increase the recovery of transformed, regenerated plants (Raji et al., 2018). The selectable 
marker genes used in the constructs designed for maize transformation include antibiotic-resistant neomycin phosphotransferase II (nptII; Breyer et al., 2014; Barone et al., 2020; Hoerster et al., 2020), hypoxanthine phosphoribosyl transferase ( $h p t$; Ishida et al., 2007) and the herbicide resistance genes phosphinothricin $\mathrm{N}$-acetyltransferase (pat/bar; Frame et al., 2002; Ishida et al., 2003) and acetolactate synthase (Hra/als; Zhang et al., 2005; Hoerster et al., 2020). Selectable herbicide markers commonly confer a trait that is highly desired in agronomic performance (Que et al., 2014). The use of bar/pat genes as a selective marker allows the selection of transformed calli with phosphinothricin (PPT) or its derivatives and has been shown to be very effective for the selection of transformed maize plants (Wang et al., 2009; Que et al., 2014; Yadava et al., 2017). Other selection systems based on the metabolism of sugars (mannose) and amino acids (D-serine and D-alanine) have emerged (Que et al., 2014; Yadava et al., 2017).

\section{Improvement of Agrobacterium Strains}

Agrobacterium strains have been improved to achieve increased plant transformation frequency through the development of binary vectors (Zambryski et al., 1982; Hoekema et al., 1983; Bevan, 1984; Komari et al., 2006), the development of ternary helper plasmids and superbinary vectors (Ishida et al., 1996; Anand et al., 2018; Zhang et al., 2019), the upregulation of virulence (vir) gene expression (Ishida et al., 1996; Van Der Fits et al., 2000; Ye et al., 2011; Vaghchhipawala et al., 2018), and the removal of negative factors of T-DNA transfer (Nonaka et al., 2019). Genome editing has also helped improve Agrobacterium strains themselves. For example, clustered regularly interspaced short palindromic repeats (CRISPR)-mediated lossof-function mutations in recA have generated an EHA105 strain with improved performance for maize transformation (Rodrigues et al., 2021). RecA-deficient strains are typically used to avoid the recombination of additional virulence genes from ternary helper plasmids with homologous sequences from the Ti plasmid (Mookkan et al., 2017; Anand et al., 2018; Sardesai et al., 2018), which allows their concomitant use with ternary vectors harbouring additional virulence genes and morphogenic regulators to increase plant regeneration.

Other features may also be manipulated to improve Agrobacterium-mediated transformation and the fate of transformed events. For example, the subversion of host plant factors (Pitzschke, 2013; Sardesai et al., 2013; Hwang et al., 2015), the reduction of vector backbone and transposon integration (Ülker et al., 2008; Kim and An, 2012; Jupe et al., 2019), the increase of T-DNA transfer capacity (Nonaka et al., 2019), the environmental containment of Agrobacterium when used for field applications (Torti et al., 2021), the increase on transient transformation frequency (Wang et al., 2018) and the use of effective tools for non-invasive monitoring of gene expression and plant transformation ( $\mathrm{He}$ et al., 2020; Xu et al., 2021).

Another promising perspective is the use of autonomously replicating virus-based vectors (Zaidi and Mansoor, 2017) for overexpression, gene silencing, or gene editing in maize via
Agrobacterium (Ding et al., 2006; Wang et al., 2016; Jarugula et al., 2018; Gao et al., 2019; Hu et al., 2019; Mei et al., 2019; Xie et al., 2021). These technologies have allowed transient expression at an industrial scale by spraying Agrobacterium carrying the viral vector (Torti et al., 2021). Bypassing difficulties, such as low transient gene transfer rates, regeneration difficulties, and host cell integrity issues (Zaidi and Mansoor, 2017; Nonaka et al., 2019), the virus-based vectors could be optimized to allow the development of transient expression strategies for CRISPR-Cas gene editing without the stable integration of foreign DNA.

\section{Standard Protocol for Maize Transformation}

A basic protocol based on published data (Ishida et al., 1996; Frame et al., 2002; Zhao et al., 2002; Huang and Wei, 2005; Frame et al., 2006; Ishida et al., 2007; Vega et al., 2008; Lee and Zhang, 2016) is currently being used for routine maize transformation using IZEs as explant in many laboratories worldwide. The main steps of this routine maize transformation (Figure 1) involve plant growth under controlled conditions (Figure 1A), harvesting ears at 10-16 days post-pollination, selecting 1.2-2-mm IZEs (Figures 1B-C), infecting with Agrobacterium harbouring the desired construct (Figure 1D), monitoring the infection rate using GUS-harbouring vectors (Figure 1E), incubating the infected embryos in the dark at $21^{\circ} \mathrm{C}$ for resting (Figure 1F), transferring the infected embryos to the first-round selective medium in the dark at $25^{\circ} \mathrm{C}$ (Figure 1G), transferring the infected embryos to the secondround selective medium in the dark at $25^{\circ} \mathrm{C}$ (Figure 1H), transferring the resistant embryogenic calli to the first-round regeneration medium in the dark at $25^{\circ} \mathrm{C}$ (Figure 1I), transferring the regenerating plants to second-round regeneration medium to rooting in penumbra light (16hs) at $25^{\circ} \mathrm{C}$ (Figures 1J-K), transferring the regenerated plants to the acclimation room at $26^{\circ} \mathrm{C} / 22^{\circ} \mathrm{C}$ day/night, $16 \mathrm{~h}$ light (Figure 1L) and finally transferring the acclimated plants to the greenhouse for plant growth and $\mathrm{T}_{1}$ seed production (Figures $\mathbf{1 M - O}$ ).

When growing plants for IZE harvesting, environmental factors should be taken into account. For the B104 genotype, the recommended greenhouse temperature varies between $20^{\circ} \mathrm{C}$ and $28^{\circ} \mathrm{C}$ (night/day), and light intensity varies between 600 and $1,000 \mu \mathrm{mol} \cdot \mathrm{m}^{-2} \cdot \mathrm{s}^{-1}$. Fine-tuning the temperature and light are essential to the production of high-quality embryos for successful transformation. For routine transformation throughout the year, the plants are pollinated weekly, and the IZEs reach their ideal size 10-16 days after pollination. The harvested ears can be stored at $4{ }^{\circ} \mathrm{C}$ for a couple of days prior to use. The Agrobacterium strains EHA101, EHA105 and LBA4404 are commonly used for the transformation of IZEs. After infection in N6 liquid medium (Figure 1D), the IZEs are laid down on cocultivation medium for 3 days in the dark at $21^{\circ} \mathrm{C}$ (Figure 1F). The cocultivation medium is similar to the infection medium with the exception that the N6 salts are substituted by MS salts (Frame et al., 2006). The infection occurs mainly in the scutellum cells facing upward (Figure 1E). After 3 days 

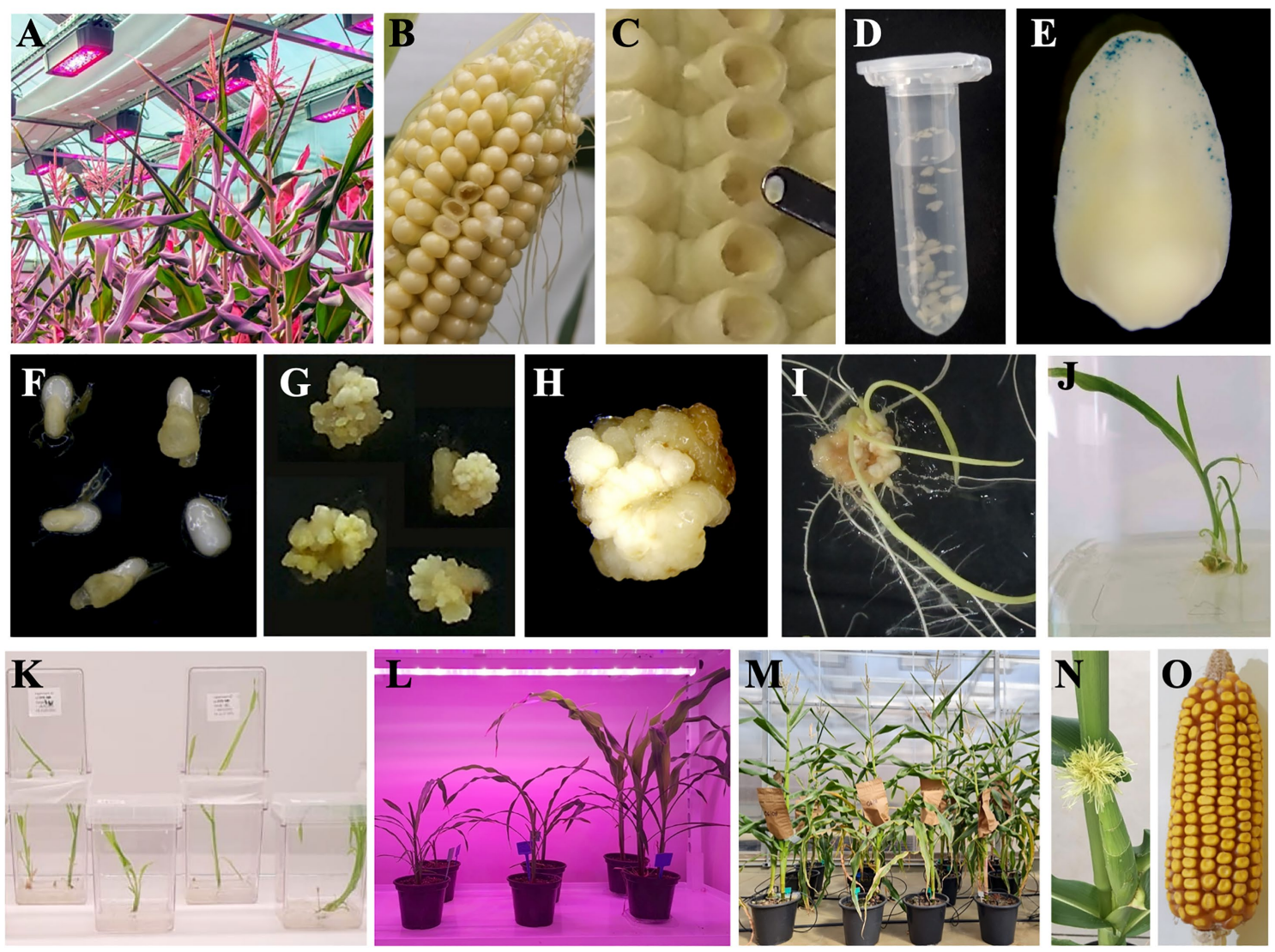

FIGURE 1 | Standard protocol for B104 maize transformation. (A) Growth of donor plants for immature embryo production under greenhouse-controlled conditions. (B) Ears are harvested 10-16 d after pollination. (C) The immature zygotic embryo reaches the ideal size of 1.2-2 mm. (D) Isolated immature embryos in co-cultivation. (E) Immature embryo transiently expressing the gus reporter gene. (F) Embryos in resting media seven days after Agrobacterium infection. (G) Calli induction on selection I medium. (H) Compact type I callus in selection II medium. (I,J) Regeneration of transformed plants. (K) Transformed plantlets with roots and shoots are grown in the penumbra room. (L) $\mathrm{T}_{0}$ transgenic individuals rooted in the soil in an acclimation room. (M) $\mathrm{T}_{0}$ plants grown at the greenhouse. (N) Flowering and pollination of $T_{0}$ plants at the greenhouse. (0) Harvesting of $T_{1}$ seeds. The complete process, from infection to $T_{1}$ seed production, takes approximately $6-8$ months. The images are not to scale.

in the cocultivation medium, the IZEs are transferred to a resting medium containing the same composition of cocultivation medium with the appropriate antibiotics for bacterial counterselection for 7 days at $21^{\circ} \mathrm{C}$ in the dark (Figure 1F). The IZEs are then transferred to a selective medium containing a low concentration of the PPT selective agent for 14 days (Figure 1G) and then to a selective medium containing an increased concentration of the selective agent for 28 days (Figure 1H). The selective agent depends on the construct selectable marker being the most popular bar gene that confers bialaphos/phosphinothricin (PPT) resistance (Gordon-Kamm et al., 1990; Frame et al., 2002). In this case, PPT is first used at $1,5 \mathrm{mg} / \mathrm{l}$ for 14 days, followed by 28 days at $5 \mathrm{mg} / \mathrm{l}$. Other selectable marker genes widely used include $n p t I I$, which confers kanamycin resistance (Breyer et al., 2014; Barone et al., 2020; Hoerster et al., 2020), and hra, which confers imazapyr resistance (Hoerster et al., 2020) and pmi for resistance to mannose (Dong et al., 2021). In general, embryogenic callus induction is completed after 2 weeks on low-concentration selective medium (Figure 1G). Maize genotypes able to produce type II calli exhibit early embryogenesis with the rapid proliferation of somatic embryos, whereas genotypes that produce type I callus genotypes exhibit late embryogenesis with organogenic and meristematic domes showing more compact tissues (Kausch et al., 2021b). After the selection phase, the selected calli are fragmented and transferred to regeneration medium without hormones containing the maximum concentration of selective agent $(6 \mathrm{mg} / \mathrm{l}$ of PPT, Figure 1I) and without hormones for 3 weeks and then to regeneration medium without hormones and selective agents at low light intensity for 2-4 weeks (Figures 1J-K). Regenerated plantlets with roots and shoots are finally transferred to soil and acclimated until the plants are in appropriate condition to be transferred to the greenhouse (Figures 1L-M). The transformation time, from Agrobacterium infection to $T_{1}$ seeds takes approximately 6-8 months (Figure 10).

\section{Maize Transformation Service Providers}

Despite recent advances in maize transformation, only a few academic groups worldwide have the necessary infrastructure 
to effectively implement maize transformation. Although improved protocols are available, the steps from immature embryos to $\mathrm{T}_{1}$ seeds require well-equipped laboratory and greenhouse facilities for the Agrobacterium-mediated transformation (Wang et al., 2009; Altpeter et al., 2016). In addition to a high-quality infrastructure, the availability of skilled personnel is another factor determining the success of maize transformation. Due to these constraints, several specialized public and private facilities currently offer maize transformation services (Table 1). B104 and Hi-II are the most used genotypes by maize transformation service providers. Public and private maize transformation providers are available in the USA, Brazil, India, and Europe (Table 1).

\section{EMERGING TECHNOLOGIES FOR MAIZE TRANSFORMATION}

\section{Overcoming Genotype Recalcitrance: Morphogenic Regulator-Mediated Transformation}

Although routinely performed, maize transformation faces the constraints of a few genotypes amenable to Agrobacteriummediated transformation. The maize inbred line B73, for instance, is an important genetic and genomic resource but is strongly recalcitrant to transformation. The same is true for most of the commercial elite maize inbred lines. In addition, even the most improved transformation protocol currently available requires a callus culture step, which is laborious, time-consuming and constitutes a constraint for efficient large-scale transformation pipelines (Lowe et al., 2016). New methods relying on morphogenic regulators (MRs) expression at the early steps of maize transformation have been developed to overcome these obstacles. MRs, such as BABY BOOM (BBM), OVULE DEVELOPMENT PROTEIN 2 (ODP2), and WUSCHEL 2 (WUS2), are transcription factors capable of inducing somatic embryogenesis in different plant tissues. Transformation vectors harbouring combinations of WUS2 with either BBM (Lowe et al., 2016, 2018; Mookkan et al., 2017; Barone et al., 2020) or ODP2 (Svitashev et al., 2016) along with selectable markers and target genes have demonstrated high transformation frequency. In general, these Morphogenic Regulator-Mediated Transformation (MRMT) vectors can be introduced in the current Agrobacterium strains and used for immature embryo transformation. The MR methods exhibit two significant benefits: (1) increased plant regeneration rates and the recovery of transformed plants from recalcitrant genotypes and (2) a shortening in the overall time needed for transformation by bypassing the callus culture step (Figure 2A).

The first published MRMT method demonstrated that the use of vectors harbouring BBM and WUS2 for either Agrobacterium- or particle bombardment -mediated transformation increased the transgenic events recovery from recalcitrant genotypes by 25 to $52 \%$ (Lowe et al., 2016). Soon after, a transformation frequency of $15 \%$ was obtained for the recalcitrant B73 inbred line (Mookkan et al., 2017). Despite
TABLE 1 | Academic laboratories and facilities providing maize transformation services.

\begin{tabular}{|c|c|c|c|}
\hline Country & Laboratory/Facility & $\begin{array}{l}\text { Maize } \\
\text { Genotype }\end{array}$ & Website \\
\hline Argentina & INDEAR & NA & $\begin{array}{l}\text { https://www.indear. } \\
\text { com/en/plant- } \\
\text { transformation-and- } \\
\text { tissue-culture/ }\end{array}$ \\
\hline Belgium & $\begin{array}{l}\text { VIB Crop Genome } \\
\text { Engineering Facility }\end{array}$ & B104 & $\begin{array}{l}\text { https://www.psb. } \\
\text { ugent.be/cores/crop_ } \\
\text { genome_engineering_ } \\
\text { facility }\end{array}$ \\
\hline Brazil & Pangeia Biotech & $\mathrm{Hi}-I I$ & $\begin{array}{l}\text { https://www. } \\
\text { pangeiabiotech.com/ }\end{array}$ \\
\hline Germany & $\begin{array}{l}\text { Crop Genetic } \\
\text { Systems }\end{array}$ & $\begin{array}{l}\text { A188 B104 } \\
\text { Hi-II }\end{array}$ & $\begin{array}{l}\text { https://www.crop- } \\
\text { genetic-systems.de/ } \\
\text { english/prices/ }\end{array}$ \\
\hline India & Metahelix & $\begin{array}{l}\text { Tropical/ } \\
\text { Temperate }\end{array}$ & $\begin{array}{l}\text { https://www.rallis.co. } \\
\text { in/Seed_Division/main/ } \\
\text { pt_transformation.html }\end{array}$ \\
\hline USA & $\begin{array}{l}\text { Wisconsin Crop } \\
\text { Innovation Center }\end{array}$ & Hi-II LH244 & $\begin{array}{l}\text { https://cropinnovation. } \\
\text { cals.wisc.edu/ } \\
\text { services/maize- } \\
\text { transformation/ }\end{array}$ \\
\hline USA & $\begin{array}{l}\text { Cornell CALS - } \\
\text { College of Agriculture } \\
\text { and Life Sciences }\end{array}$ & B104 & $\begin{array}{l}\text { https://cals.cornell. } \\
\text { edu/school- } \\
\text { integrative-plant- } \\
\text { science/about/ } \\
\text { campuses-facilities/ } \\
\text { plant-transformation- } \\
\text { facility }\end{array}$ \\
\hline USA & $\begin{array}{l}\text { Plant Transformation } \\
\text { Core Facility at the } \\
\text { University of Missouri }\end{array}$ & Hi-II B104 & $\begin{array}{l}\text { https://research. } \\
\text { missouri.edu/ptc/ } \\
\text { services.php }\end{array}$ \\
\hline USA & $\begin{array}{l}\text { Danforth Center Core } \\
\text { Facilities }\end{array}$ & NA & $\begin{array}{l}\text { https://www. } \\
\text { danforthcenter.org/ } \\
\text { our-work/core- } \\
\text { facilities/plant- } \\
\text { transformation/ }\end{array}$ \\
\hline USA & $\begin{array}{l}\text { Plant Transformation at } \\
\text { The University of } \\
\text { Rhode Island }\end{array}$ & $\mathrm{Hi}-I I$ & $\begin{array}{l}\text { https://web.uri.edu/ } \\
\text { pbl/plant- } \\
\text { transformation/ }\end{array}$ \\
\hline USA & Creative Biogene & $\begin{array}{l}\mathrm{Hi}-\| \text { B104 } \\
\text { Others }\end{array}$ & $\begin{array}{l}\text { https://www.creative- } \\
\text { biogene.com/services/ } \\
\text { maize-transformation- } \\
\text { service.html }\end{array}$ \\
\hline
\end{tabular}

this transformation success, the continuous expression of MRs can lead to various developmental defects. Thus, the expression of MRs needs to be restricted to the embryogenesis induction step. Two approaches have been developed to overcome these detrimental effects: (1) excision of the MR expression cassette by a recombination system and (2) driving the expression of MRs using specific promoters. To date, CREATES RECOMBINATION (CRE) flanked by loxP sites has been the recombination system of choice for the excision of MR genes from expression cassettes (Lowe et al., 2016; Mookkan et al., 2017; Zhang et al., 2019; Hoerster et al., 2020; Masters et al., 2020). The transformation vectors include a region containing both the MRs and CRE/loxP, whose expression is driven by 


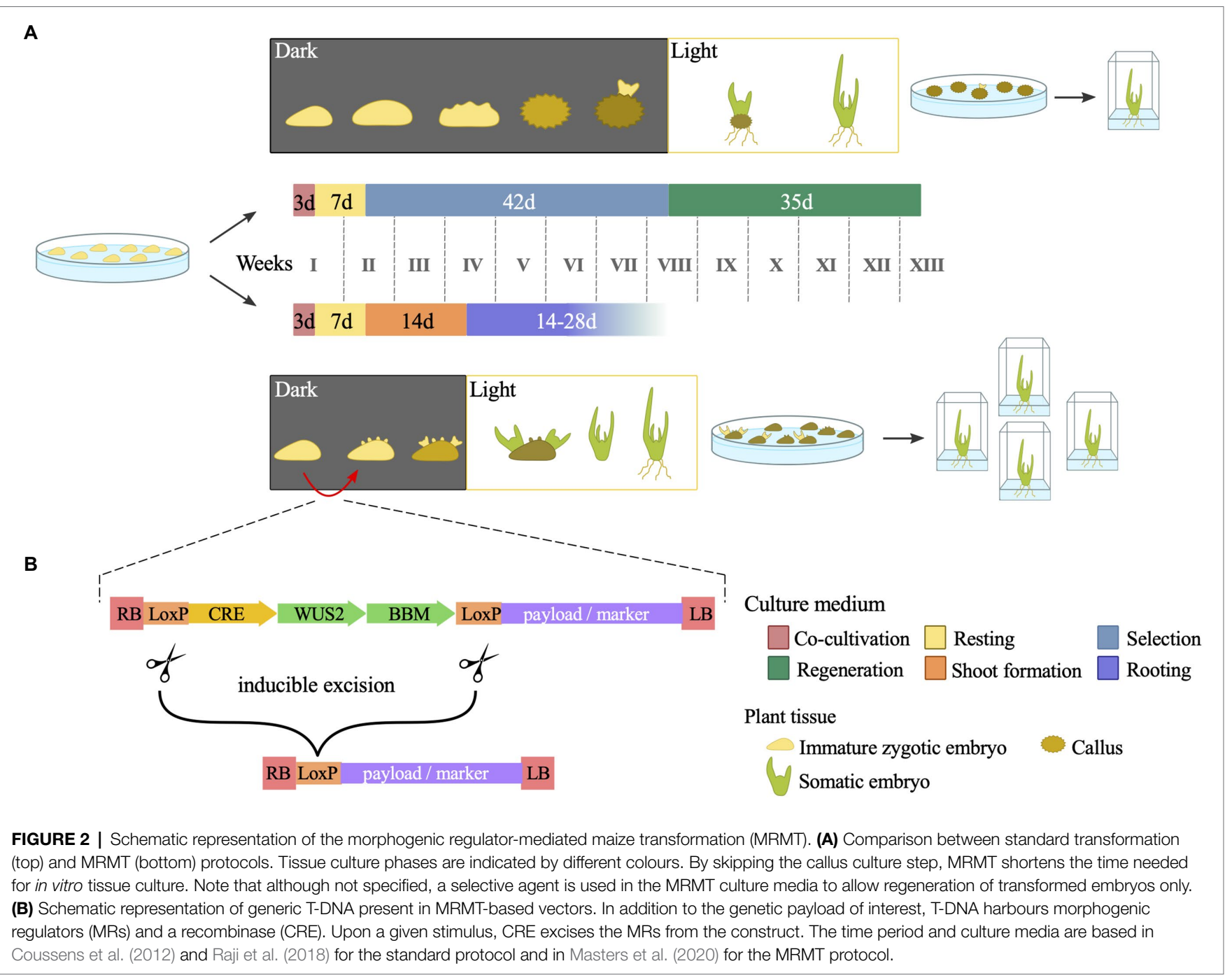

inducible promoters that can be triggered after the first steps of somatic embryogenesis induction to excise the MR cassette (Figure 2B). Examples of inducible promoters are those driving the drought-responsive Rab17 gene (Lowe et al., 2016; Mookkan et al., 2017; Zhang et al., 2019) or the heat-inducible Hsp17.7 gene (Masters et al., 2020). The selection of successful excision events may be facilitated by a fluorescent protein, which is only expressed after full excision of the CRE/loxP cassette.

A potential downside factor is that the quality of events may be affected because recombination is hardly $100 \%$ efficient and may leave part of the MR cassettes in the genome of the transformed events. Nevertheless, the frequency of complete recombination in transformed events ranges from 61 to $83 \%$ (Zhang et al., 2019). Another method avoids such drawbacks using specific promoters to drive MR expression. The rationale of this method is to maintain the expression of MRs in calli, embryos, and young leaves while avoiding its expression in meristems, roots, and reproductive organs. The use of a maize phospholipid transferase protein promoter (ZmPLTP) and an auxin-inducible promoter (ZmAXIG1) to drive BBM and WUS2 expression, respectively, allows the recovery of healthy transformed plants without excision of the MRs (Lowe et al., 2018). The MR induction of somatic embryos seems to be genotype independent, as observed with more than 22 inbred lines from DuPont Pioneer (Lowe et al., 2018). Moreover, MR methods also have the advantage of inducing somatic embryogenesis directly from the scutellum epidermis, which skips the initial stage of callus formation and thus halves the time needed for in vitro culture prior to transferring the plants to a greenhouse (Figure 2A; Lowe et al., 2018).

Recently, an alternative method was proposed to avoid the integration of MRs in the genome of transformed events by infecting immature embryos with two Agrobacterium strains: one harbouring a construct with the selectable marker and target genes, and the other harbouring the MR construct (Hoerster et al., 2020). Upon infection, transient expression from the MR cassette induces somatic embryogenesis, whereas only embryos containing the selectable marker and target gene constructs integrated into the plant genome are recovered. The expression of WUS2 is driven by the PLTP promoter incorporating 
viral enhancers that increase the induction of somatic embryogenesis and counterselect embryos in which the MR construct is eventually integrated because the high expression of WUS2 inhibits regeneration (Hoerster et al., 2020). In addition to WUS2 and BBM/ODP2, other MRs, such as GROWTHREGULATING FACTOR 5 (GRF5) and chimeric GRF-INTERACTING FACTOR 1 (GRF4-GIF1), have been shown to increase the recovery of transgenic events (Debernardi et al., 2020; Kong et al., 2020).

MRs have been helpful for CRISPR/Cas9 genome editing, which usually demands the screening of many edited events (Zhang et al., 2019; Barone et al., 2020). In addition, genome editing based on less efficient systems, such as homologous recombination (HR), can benefit even further from a higher embryo recovery rate (Barone et al., 2020). MR transformation has also been efficient for CRISPR/Cas9 ribonucleoprotein (RNP) gene editing. In this case, IZE is co-bombarded with the RNPs of interest together with DNA constructs containing the MRs (Svitashev et al., 2016). This approach allows the recovery of foreign DNA- and marker-free GE plants. MR-based ternary vectors built by combining different backbones, helper plasmids, and recombination systems have been shown to be effective for maize CRISPR/Cas9 genome editing (Zhang et al., 2019). The commercially available "ready-to-use" vector is compatible with Golden Gate cloning for assembling the sgRNA expression cassette (Zhang et al., 2019).

\section{Haploid-Inducer Mediated Genome Editing System}

CRISPR-Cas genome editing (CGE) in plants has evolved enormously in the past few years. The first efficient CGE process in plants was demonstrated in 2013 by three independent groups, which edited genes in rice, wheat, Nicotiana benthamiana, and Arabidopsis thaliana (Li et al., 2013; Nekrasov et al., 2013; Shan et al., 2013). As a result, CGE has become the most accessible, efficient, and versatile genome-editing tool for plants (Chen et al., 2019). In general, CGE uses a Cas9 endonuclease and a chimeric single guide RNA (sgRNA) that drives Cas9 to a target DNA sequence in the genome (Charpentier and Doudna, 2013). A range of CRISPR-Cas toolkits have been made available for major crops (Chen et al., 2019), to be used for various aims, including the simultaneous editing of multiple traits and precise allelic replacements (Svitashev et al., 2015; Shi et al., 2017; Chen et al., 2019; Kelliher et al., 2019; Wang et al., 2019; Ahmar et al., 2020; Liu et al., 2020; Van Tassel et al., 2020; Zhang et al., 2020a; Gao et al., 2020b). However, a frequent bottleneck of the technique is the delivery of CRISPR-Cas by standard Agrobacterium or biolistic methods because most crop varieties are recalcitrant to transformation.

Effective methods to deliver the CRISPR-Cas machinery in germplasm recalcitrant to gene editing by crossing have been proposed (Li et al., 2017; Kelliher et al., 2019; Wang et al., 2019). Direct genome-editing technologies, including desiredtarget mutator (DTM; Li et al., 2017; Qi et al., 2020) and HI-Edit (Kelliher et al., 2019), which is also known as IMGE (Wang et al., 2019), are based on the pollination of elite recipient inbred lines using the pollen of a stably transformed line harbouring a CRISPR-Cas construct (Figures 3-4). In DTM, the target gene is directly edited in a desirable allele via transacting CRISPR-Cas (Figures 3A-C). The trans editing can occur by (1) the delivery of Cas RNPs, which are expressed by the sperm cell, directly into the egg cell of the elite line (gametophytic expression) and (2) the expression of Cas and sgRNA in the zygote after gamete fusion (zygotic expression; Figure 3D). Both CRISPR-Cas systems depend on the promoter used to drive cassette expression (e.g.: pollen-specific promoter versus constitutive promoter, Jacquier et al., 2020). Thus, after subsequent crossing, CRISPR-Cas-free plants with the original receptor genetic background that are homozygous for the desired edited gene can be obtained (Figures 3C,E). Although backcrossings are needed to recover the original genotype, this method dramatically reduces the workload of introgression breeding programs that usually need marker-assisted backcrossing and more generations to minimize the linkage drag effect (Peng et al., 2014; Li et al., 2017).

In the HI-Edit/IMGE method, the paternal genome is a haploid inducer line harbouring a CRISPR-Cas cassette used to pollinate the maternal elite line (Figure $\mathbf{4 A}$ ). In this case, the maternal genome is edited in trans, whereas the male genome is eliminated at the zygote phase. The haploid progeny, which is typically sterile, are then screened for CRISPR-Cas-induced mutations (Figure 4B) and subsequently treated with a colchicine mitotic inhibitor (Prasanna et al., 2012; Melchinger et al., 2016; Chaikam et al., 2019) or another less toxic doubling agent (Geiger and Gordillo, 2009; Häntzschel and Weber, 2010) to produce fertile doubled haploid and gene-edited nontransgenic plants (Kelliher et al., 2019; Wang et al., 2019; Figures 4C-E). However, improvements are needed to overcome the inherent problems related to haploid induction per se (Trentin et al., 2020; Jacquier et al., 2021). For example, CRISPR-Cas can be used before or in parallel to HI-Edit to: (1) increase the haploid induction rates by targeting genes related to high haploid induction (Kelliher et al., 2017; Zhong et al., 2019) or genes related to the inducer exclusion (Kelliher et al., 2019); (2) accelerate and accurately sort kernels/seedlings with haploid embryos from normal embryos by modifying visual traits such as anthocyanin (Chaikam et al., 2019) or by integrating visible transgenic markers into the inducers (Yu and Birchler, 2016; Xu et al., 2021; Yan et al., 2021) or even targeting genes involved in the oil content of seeds (Melchinger et al., 2013) and fixing recessive alleles of morphological traits in donors (Trentin et al., 2020). Care should be taken with desirable/undesirable agronomic traits during induction of haploid plants that would compromise the breeding programmes (Trentin et al., 2020). Desirable agronomic traits could be further targeted by gene editing, to take full advantage of HI-Edit/IMGE technology.

Overall, DTM and HI-Edit/IMGE technologies can help stack favourable genes in the genomes of elite lines. Precise genome modification overcomes the difficulties of traditional random uncontrolled mutagenesis and unpredictable insertions into the plant genome and thus has potential positive impacts on plant breeding (Schiemann et al., 2019). As a potential drawback, the CRISPR-Cas technology can generate undesirable 
A

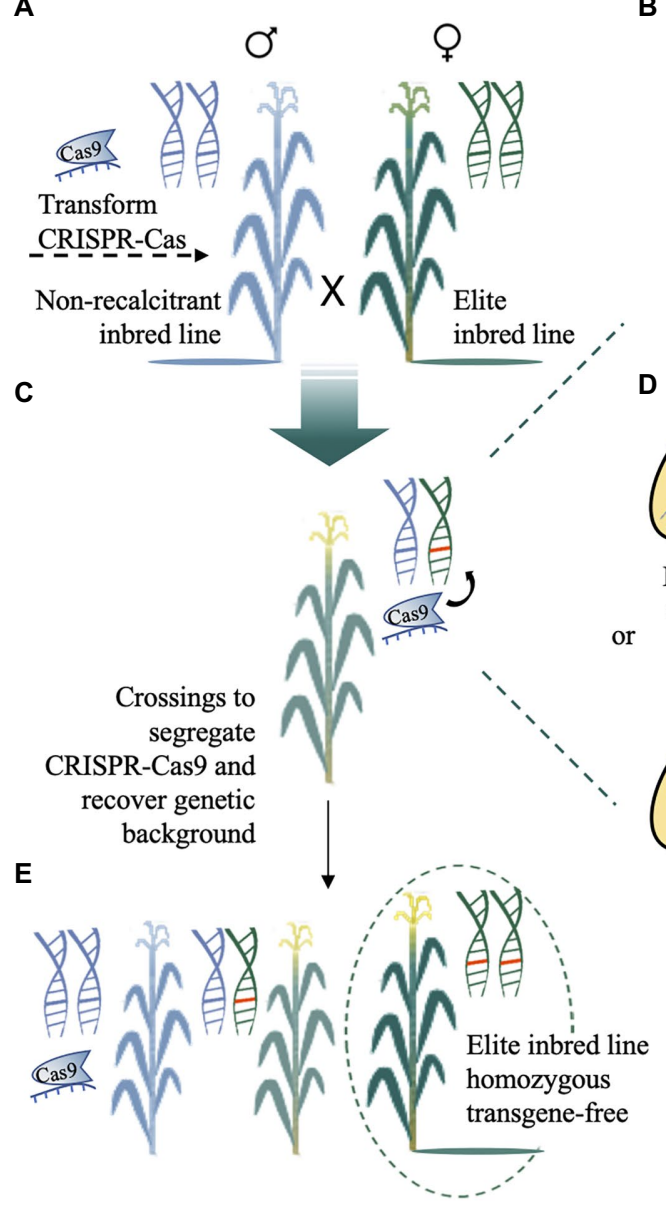

D

西
B

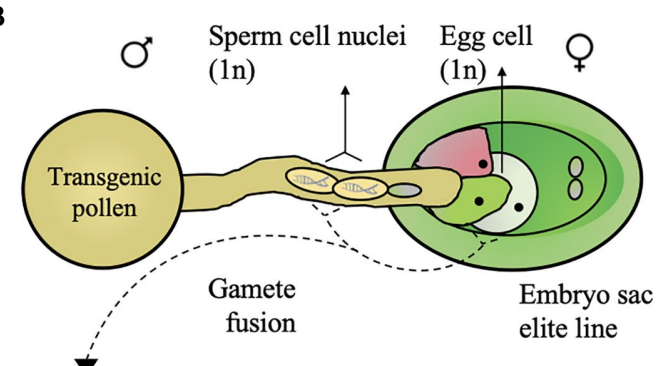

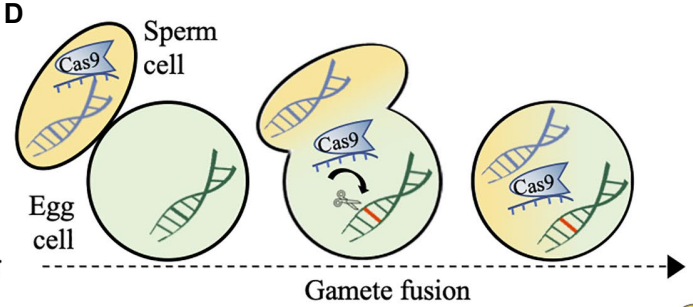

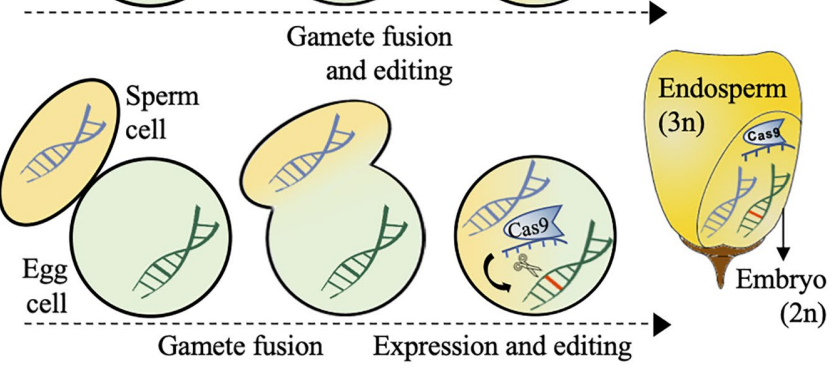

FIGURE 3 | Schematic representation of the desired-target mutator (DTM) maize transformation. (A) The CRISPR-Cas cassette can be transformed into a nonrecalcitrant inbred line for trans editing in an elite recalcitrant inbred line. (B) Pollen carrying a CRISPR-Cas cassette designed to target gene(s) of interest was used to pollinate the elite maize line. (C) The target gene is directly edited via trans-acting CRISPR-Cas. (D) The delivery of RNP, which is expressed by the sperm cell, directly into the egg cell of the elite line (gametophytic expression) or expression of RNP in the zygote after gamete fusion (zygotic expression) generates a hybrid edited embryo. (E) After trans editing, subsequent crossings are needed to obtain CRISPR-Cas-free plants with the original receptor genetic background and homozygous to the desired mutation. The schematic illustration view in (D) was adapted from Jacquier et al. (2020).

off-targets but, although frequently predicted in silico, has been shown to occur rarely in plants (Young et al., 2019; Graham et al., 2020; Herbert et al., 2020; Gao et al., 2020a).

\section{Nanoparticle-Mediated Transformation}

As discussed in previous sections, new technologies have pushed maize transformation (especially that aiming at genome editing) closer to a genotype-independent status in the past few years. These tools have enabled achieving levels of efficiency and scale that are practicable at academic and industrial settings.

Another promising technology employs nanoparticle-mediated (NP) delivery of macromolecules in a tissue culture-independent manner. The major advantages of NPs reside in their small sizes, diverse geometries, and versatile surface activation and binding capabilities (Cunningham et al., 2018). Although the exclusion limit of cell membranes is approximately $500 \mathrm{~nm}$, that of plant cell walls ranges from approximately 5 to $20 \mathrm{~nm}$ (Cunningham et al., 2018) and is thus the major size-limiting barrier for introducing materials intracellularly. Carbon nanotubes (CNTs), a type of NP with a size of at most $\sim 20 \mathrm{~nm}$ in one dimension, can avoid the requirements for harsh entry methods that frequently result in cell damage. Indeed, the passive delivery of biomolecules into leaf cells of intact plants and the protection of polynucleotides from nuclease degradation have been observed with $\leq 12$-nm single-walled carbon nanotubes (SWCNTs; Demirer et al., 2019). Furthermore, NPs can adsorb and carry a variety of cargo chemistries into cells, including DNA, RNA, proteins, RNPs, and small molecules (Cunningham et al., 2018), which makes NPs suitable for various approaches, which not only include genetic modification but also gene expression and pharmacological perturbations.

\section{Pollen Transformation}

Tissue culture-independent methods for plant transformation in plants have been limited to a few species-tissue/cell type systems (for recent reviews, see Kausch et al., 2021a, 2021b 


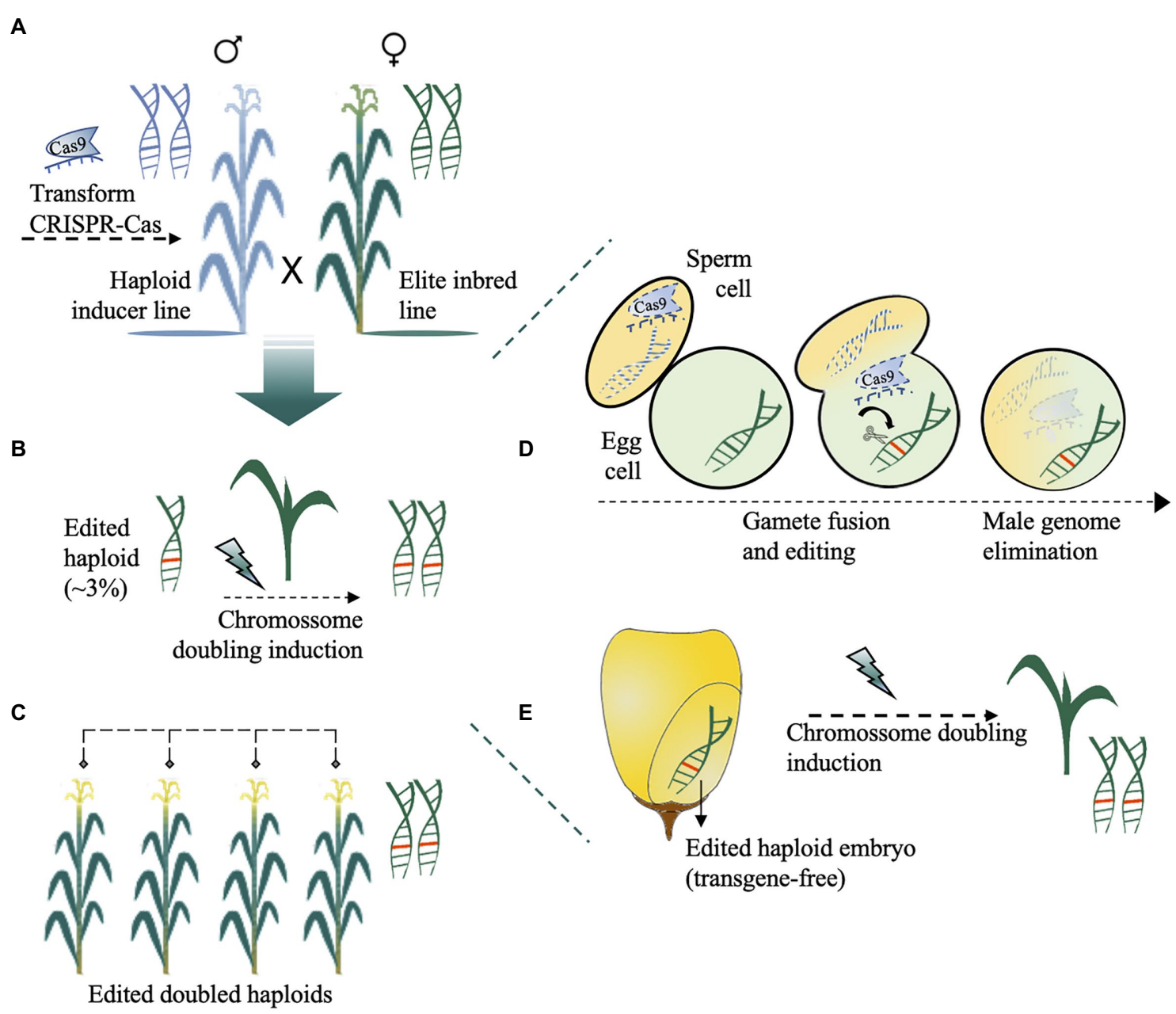

FIGURE 4 | Haploid-inducer-mediated genome editing (IMGE) or simultaneous double haploid production and editing (HI-Edit) in maize. (A) The haploid inducer line harbouring a CRISPR-Cas cassette is used to pollinate the maternal elite line of any genotype. (B) The haploid progeny, which are typically sterile, were screened for CRISPR-Cas-induced mutations ( $3 \%)$ and subsequently treated with a doubling agent to produce fertile doubled haploids. (C) Edited doubled haploid lines with improved agronomic traits are obtained after self-pollination. The zoomed view of trans genome editing and the maternal haploid formation processes occurring in B are shown in D-E. (D) After trans-acting CRISPR-Cas, and fertilization, the unstable paternal chromosome from haploid-inducer pollen is lost. (E) The formed embryo is nontransgenic (Cas-free) and has a doubled chromosome to recover the homozygous edited diploid elite plant.

and Anjanappa and Gruissem, 2021). One of these methods relies on delivering DNA constructs into mature pollen that is then used for direct pollination (Eapen, 2011). However, the methods remain controversial due to their low frequency or lack of reproducibility. In the case of maize, the aeration of pollen grains at $4^{\circ} \mathrm{C}$ in sucrose before sonication results in improved transformation (Yang et al., 2017). However, no successful transformation using this method has been published thus far.

Methods that exploit both the pollen biology and NP features are anticipated to result in significant improvements towards the realization of tissue culture-independent transformation of maize, particularly with respect to genome editing (Demirer et al., 2021), for which transgene integration is often unnecessary. In particular, subsequent advances are expected to take advantage of (1) the rapid and vigorous growth of maize pollen tubes both on stigma and in vitro (2) mounting knowledge of pollen and pollen tube gene expression and cell wall biochemistry (Zhou et al., 2017), which can inform further perturbation of their permeability, and (3) the versatile and customizable physicochemical properties and sizes of NPs, which would allow diverse cargo and passive cell entry.

\section{DEVELOPMENT OF GENETICALLY MODIFIED AND EDITED VARIETIES}

\section{Biotechnology Pipeline for Trait Development}

Over the last three decades, genetically modified (GM) maize varieties have successfully reached the market, which has brought traits such as herbicide resistance and insect resistance to farms. The first generation of varieties incorporated a single gene 
with only one mode of action against one insect order for insect resistance. The following generations were obtained by crossing herbicide and insect resistant events and different insect resistance events to achieve multiple modes of action against different insect orders. These so-called stacking varieties have reached impressive success with farmers, as demonstrated by a clear and complete phenotypic outcome (ISAAA database, 2021). The development of these first-generation traits is somewhat obvious because the science behind this development was described very early in the literature. However, the related process for quantitative traits such as abiotic stress tolerance, nutrient use efficiency, and yield is substantially more complex because these traits involve multiple genes that are subjected to strong environmental influence. To explore the impact of single genes on complex traits, companies have developed programmes ranging from gene to field biotechnology pipelines to evaluate gene effects at a large scale (Simmons et al., 2021).

A typical biotechnology pipeline (Mumm, 2013; Prado et al., 2014; Simmons et al., 2021) involves the following phases: discovery, proof of concept, early development, advanced development, prelaunch, and launch of commercial varieties (Figure 5). Some phases have activities that overlap temporarily, particularly when a positive early discovery lead is found, and the optimization activities begin before the end of the validation. The gene discovery phase is challenging, costly, and uncertain, particularly for traits such as drought and yield, which require well-defined phenotypic responses to drive the search for candidate genes (Nuccio et al., 2018; Simmons et al., 2021). High-throughput phenotypic screening of model plants, usually A. thaliana and O. sativa, is used to test hundreds of candidate genes. The proof-of-concept phase is characterized by the generation of events for each candidate gene and the initial phenotypic testing in both controlled environments and smallscale field trials (Simmons et al., 2021). At the end of this phase, maize events showing good agronomic performance, stable trait expression, and inheritance are elected as leads. In the early development phase, lead optimizations to improve the stability and enhance protein expression are usually required, and the leads are molecularly characterized and tested in largescale field trials on multiple target locations and years (Simmons et al., 2021). The advanced development phase is characterized by the introgression of validated leads on commercial lines, and this process often involves the use of molecular markers to accelerate the breeding process and ensure trait conversion (Mumm, 2013). Regulatory data on gene product toxicity, allergenicity, compositional analysis, and environmental and human safety are also generated. In the prelaunch phase, the number of seeds from the new GM variety are increased to reach the market, quality control is implemented to secure trait identity and purity, a regulatory report is submitted, and the new GM trait hybrid is prepared for commercial launch. Depending on the trait and the resources available, completion of the pipeline takes, on average, 11-13 years (Mcdougall, 2011; Mumm, 2013; Nuccio et al., 2018).

The average cost to develop a commercial maize GM trait is estimated at \$50-136 million (Figure 5; Mcdougall, 2011; Mumm, 2013). Excluding the discovery phase, which can vary depending on the target trait, the advanced development and prelaunch phases are costly and time-consuming (Figure 5) because multiple field trials and regulatory studies are needed to ensure the safety and quality of the developed GM variety. However, genome editing that is free from transgene DNA sequences and is already regulated as non-GM in several countries would significantly contribute to decreasing the cost of regulatory studies and the overall costs of launching commercial varieties (Figure 5; Lowe et al., 2016; Lassoued et al., 2019).

\section{Regulatory Issues Associated With Maize GM Traits}

Since the release of the first commercial insect-resistant GM maize 25years ago (Tabashnik and Carrière, 2017; Pellegrino et al., 2018), 148 GM maize events have been approved for commercial use worldwide (ISAAA database, 2021). The global area cultivated with GM maize occupied 61 million hectares in 2019, and this area included 33 million hectares in the USA, 15 million hectares in Brazil, 6 million hectares in Argentina, and 2 million hectares in South Africa (ISAAA Brief, 2019). However, although GM crops pose no additional risks to humans and the environment compared with conventional crops (National Academies of Sciences, Engineering, and Medicine, 2016), the public constraints of the technology, particularly in the European Union, remain high (Woźniak et al., 2021). The development of new plant breeding technologies (NPBTs), such as cisgenesis, intragenesis, and genome editing, can contribute to modifying public perception, particularly if they are properly communicated to society (Cardi, 2016; Harfouche et al., 2021).

The availability of plant genomes for major crops and their wild relatives will allow the identification of genes underlying the traits of interest and their precise modification or transfer into targeted varieties (Michael and VanBuren, 2015; Cardi, 2016). In this regard, cisgenic and intragenic mutations that are based on genetic alteration within a crop genome or the transfer of genes from sexually compatible species may illuminate an amenable regulatory path (Holme et al., 2013; Schaart et al., 2016). Although the current regulatory path regarding the biosafety of cisgenes/intragenes remains complex, some of the end products are indistinguishable from conventional plant breeding products. In Australia, Canada, India, and the USA, these products are reviewed on a case-by-case basis, whereas in the European Union, cisgenic and intragenic plants are regulated as regular GM organisms (Hull et al., 2021). Although no commercial cisgenic or intragenic maize has been launched to date, studies based on the genome-wide association and genome sequencing of maize lines will certainly lead to the identification of genes with the potential to improve cultivated genotypes using a cisgene/intragene approach (Hufford et al., 2021).

Genome editing by site-directed nuclease (SDN) technologies has the potential to be widely accessible to the scientific community for the generation of biotechnology crops (van de Wiel et al., 2017). SDN applications can be divided into SDN-1, 


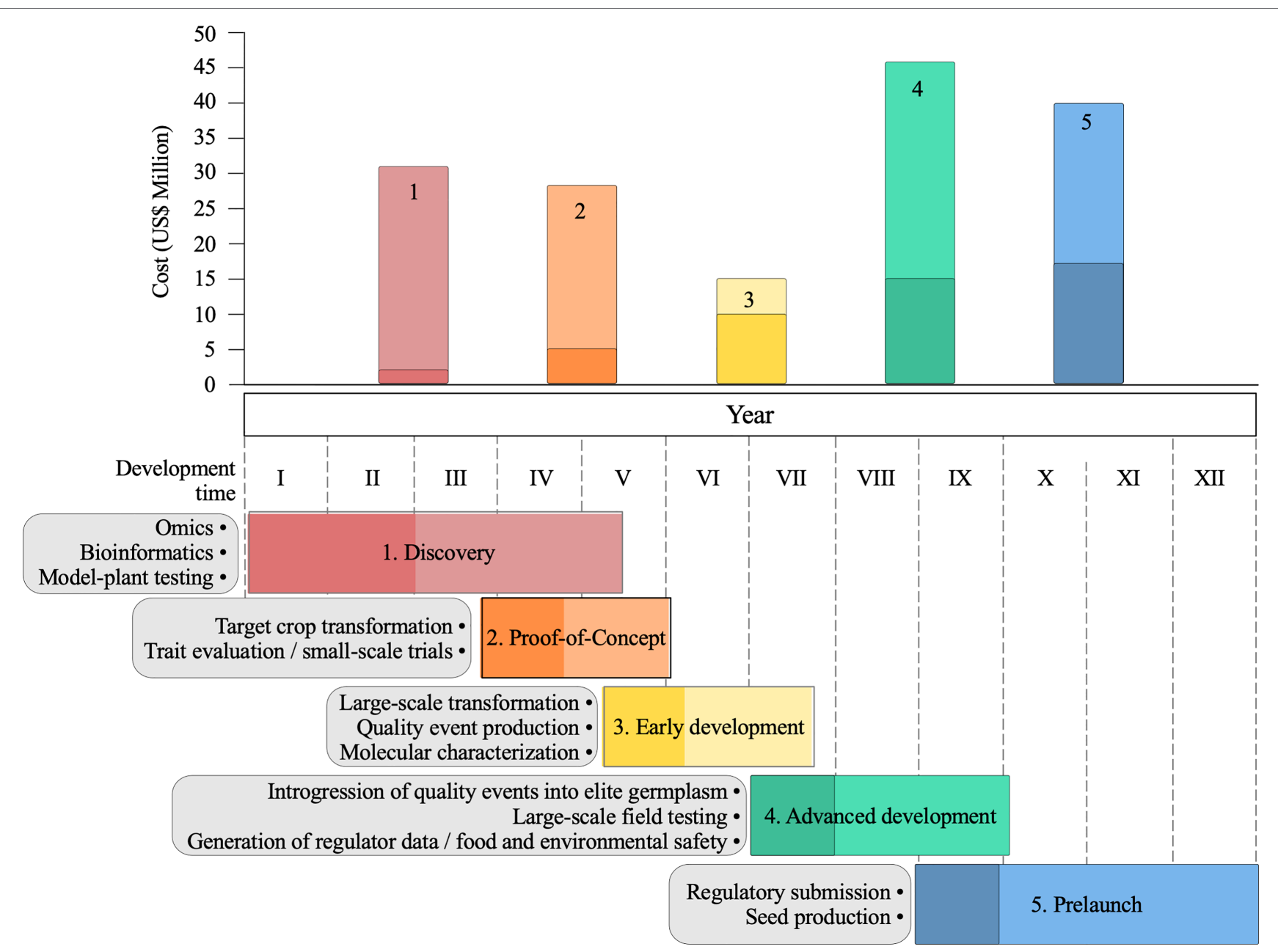

FIGURE 5 | Agricultural biotechnology pipeline for trait development in maize. General overview of main activities and estimates of maximum (light colours) and minimum (dark colours) costs and development time of each pipeline phase: discovery, proof-of-concept, early development, advanced development and prelaunch. Estimates are based on Mcdougall (2011) and Mumm (2013).

SDN-2, and SDN-3 (Grohmann et al., 2019). SDN-1 and SDN-2 generate small-sized random $(\mathrm{SDN}-1)$ or template-directed (SDN-2) mutations at predefined genomic loci and have thus been considered mimics of those resulting from natural DNA variation (Eckerstorfer et al., 2021). Thus, a handful of countries consider crops modified by SDN-1 and SDN-2 as conventional plants (Anders et al., 2021). Argentina, Chile, the USA, Canada, Brazil, Colombia, and Paraguay have already approved normative resolutions on genome editing (Eckerstorfer et al., 2019), whereas the European Union relies on the legislation of GM organisms to restrict the cultivation of genome-edited crops (Turnbull et al., 2021).

\section{Currently Approved Commercial Maize Events and Future Expectations}

The adoption of GM traits is considered the fastest innovation embraced by farmers around the world. From 1996 to 2018, the global economic gains from GM crop varieties reached
US\$ 225 billion, and 52\% of these gains were in developing countries (Brookes and Barfoot, 2020). In 2019, transgenic plants were cultivated on 190.4 million hectares in 29 countries for consumption as food and feed, and this amount represents a 112-fold increase from 1.7 million hectares in 1996. Among the most adopted crops, soybean stands out, followed by maize, cotton, and canola. Of the 193.4 million global maize cultivation areas in 2019, 31\% (60.9 million hectares) in 14 countries cultivated GM maize varieties (ISAAA Brief, 2019). Currently, maize is the crop with the most approved GM events, and 148 (36.2\%) events in 35 countries mostly combine insect resistance and herbicide tolerance traits (ISAAA Brief, 2019). Other GM traits already commercially approved for maize are the restoration of fertility, male sterility, increased drought tolerance, production of phytase, modified amino acids and alpha amylase, enhanced photosynthesis, and increased ear biomass. These approved traits represent 39 single genes (Supplementary Table S1), and the majority of these genes are related to insect (18) 
and herbicide tolerance (11). The next generation of GM maize varieties potentially coming to the market comprises events with new insecticidal proteins such as $\mathrm{Vpb} 4 \mathrm{Da} 2$, DvSnf7 RNA, and IPDO72Aa to control the population of insects already resistant to Bt (Schellenberger et al., 2016; Moar et al., 2017; Yin et al., 2020), varieties that exhibit improve grain yield by overexpressing the $z m m 28$ and ZM-BG1H1 genes (Wu et al., 2019; Simmons et al., 2020) and varieties that exhibit tolerance to drought stress by overexpressing ARGOS8 (Shi et al., 2015).

The first and only commercial genome-edited maize variety was developed by Corteva to produce a high content of amylopectin (Gao et al., 2020a). Drought stress-tolerant genomeedited maize has been developed by precise modification of the promoter region to increase the expression of the ARGOS8 gene (Shi et al., 2017). Other genome-edited maize varieties currently being developed include varieties with the traits of male sterility to facilitate hybrid development (Wan et al., 2019), tolerance to multiple stresses (Zhou et al., 2016), and dwarfism (Zhang et al., 2020b). From 2018 to 2020, several companies invested in genome editing in maize for achieving drought tolerance, resistance, and increased yield and stability, in addition to several traits investigated by government or academic institutions (USDA-APHIS, 2021).

\section{CONCLUDING REMARKS}

In this review, we discuss the recent advances in genetic transformation and its application to introducing genetically modified and edited maize events to the market. Suitable maize transformation protocols using particle bombardment and $A$. tumefaciens are available and extensively applied for maize transformation. B104 is the most a suitable genotype, particularly due to its good agronomic performance, which directly allows the production of hybrids for field trial evaluation. However, transformation and plant regeneration remain limiting factors to the generation of elite commercial maize lines. This barrier should be transposed soon through the use of genotypeindependent MRMT, which bypasses the callus phase and allows the rapid induction of somatic embryos from transformed scutellar cells. The advances in maize transformation technologies have also allowed the devising of strategies such as Hi-EDIT/ IMGE to accelerate the genome editing-driven breeding of elite maize germplasms. Thus, platforms for advanced maize biotechnology and breeding by combining genomics and genome editing and the discovery of genes and alleles for complex traits will certainly allow the development of varieties that are better adapted to the biotic and abiotic stresses imposed by global climate changes.

\section{REFERENCES}

Ahmar, S., Gill, R. A., Jung, K.-H., Faheem, A., Qasim, M. U., Mubeen, M., et al. (2020). Conventional and molecular techniques from simple breeding to speed breeding in crop plants: recent advances and future outlook. Int. J. Mol. Sci. 21:2590. doi: 10.3390/ijms21072590
The adoption of genetically modified maize varieties is already consolidated and has been shown to increase crop yields, reduce pesticide and insecticide use, and decrease the cost of crop production. However, even though GM crops are the fastest technology adopted by farmers, their acceptance by consumers remains low. The emergence of new plant breeding technologies, at least those that do not incorporate foreign DNA into the host cell, can change consumer perception and increase food security strategies. It is hoped that the new technologies discussed in this review will enable the release of more significant numbers of maize lines carrying desired traits to meet today's agriculture challenges.

\section{AUTHOR CONTRIBUTIONS}

JECTY, VCHS, JHL, RAD, IRG, FRF, PAS, LRV, VB, PA contributed with literature review and writing of different sections that compose this work. JECTY contributed with several topics, compiled topics produced by the other contributors, revised, and combined it into the final writing work. JHL and VCHS prepared the Figures. PA helped design the structure of the review and revised and defined the final version. All authors read and approved the final manuscript.

\section{FUNDING}

We are grateful to the Fundação de Amparo à Pesquisa do Estado de São Paulo (FAPESP) for supporting this research under the project "The Genomics for Climate Change Research Center (GCCRC)," grant no. 2016/23218-0. This study was funded in part by the Empresa Brasileira de Pesquisa Agropecuária (Embrapa) and the Universidade Estadual de Campinas (Unicamp). VCHS received a FAPESP postdoctoral fellowship (grant no. 2018/06442-9). JHL received a postdoctoral fellowship from Embrapa and Conselho Nacional de Desenvolvimento Científico e Tecnológico (CNPq; 381669/2019-0). LRV received a FAPESP postdoctoral fellowship (grant no. 2020/10677-1). VB received a FAPESP postdoctoral fellowship (grant no. 2020/09007-1). PAS is supported by Sempre Sementes S/A. IRG is a CNPq research fellow.

\section{SUPPLEMENTARY MATERIAL}

The Supplementary Material for this article can be found online at: https://www.frontiersin.org/articles/10.3389/fpls.2021.766702/ full\#supplementary-material

Altpeter, F., Springer, N. M., Bartley, L. E., Blechl, A. E., Brutnell, T. P., Citovsky, V., et al. (2016). Advancing crop transformation in the era of genome editing. Plant Cell 28, 1510-1520. doi: 10.1105/tpc.16. 00196

Anand, A., Bass, S. H., Wu, E., Wang, N., McBride, K. E., Annaluru, N., et al. (2018). An improved ternary vector system for agrobacterium-mediated rapid 
maize transformation. Plant Mol. Biol. 97, 187-200. doi: 10.1007/ s11103-018-0732-y

Anders, S., Cowling, W., Pareek, A., Gupta, K. J., Singla-Pareek, S. L., and Foyer, C. H. (2021). Gaining acceptance of novel plant breeding technologies. Trends Plant Sci. 26, 575-587. doi: 10.1016/j.tplants.2021.03.004

Andorf, C., Beavis, W. D., Hufford, M., Smith, S., Suza, W. P., Wang, K., et al. (2019). Technological advances in maize breeding: past, present and future. Theor. Appl. Genet. 132, 817-849. doi: 10.1007/s00122-019-03306-3

Anjanappa, R.B., and Gruissem, W. (2021). Current progress and challenges in crop genetic transformation. J. Plant Physiol. 26:153411. doi: 10.1016/j. jplph.2021.153411

Armstrong, C. L., Green, C. E., and Phillips, R. L. (1991). Development and availability of germplasm with high type II culture formation response. Maize Genet. Coop. News Lett. 65, 92-93.

Barone, P., Wu, E., Lenderts, B., Anand, A., Gordon-Kamm, W., Svitashev, S., et al. (2020). Efficient gene targeting in maize using inducible CRISPR-Cas9 and marker-free donor template. Mol. Plant 13, 1219-1227. doi: 10.1016/j. molp.2020.06.008

Bevan, M. (1984). Binary agrobacterium vectors for plant transformation. Nucleic Acids Res. 12, 8711-8721. doi: 10.1093/nar/12.22.8711

Bijman, W. J. J. (2001). How biotechnology is changing the structure of the seed industry. Int. J. Biotechnol. 3, 82-94. doi: 10.1504/IJBT.2001.000153

Breyer, D., Kopertekh, L., and Reheul, D. (2014). Alternatives to antibiotic resistance marker genes for In vitro selection of genetically modified plants scientific developments, current use, Operational Access and Biosafety Considerations. CRC. Crit. Rev. Plant Sci. 33, 286-330. doi: 10.1080/07352689. 2013.870422

Brookes, G., and Barfoot, P. (2020). GM Crops: Global Socio-economic and Environmental Impacts 1996-2018. Available at: https://pgeconomics.co.uk/ pdf/globalimpactfinalreportJuly2020.pdf (Accessed August 28, 2021).

Cardi, T. (2016). Cisgenesis and genome editing: combining concepts and efforts for a smarter use of genetic resources in crop breeding. Plant Breed. 135, 139-147. doi: 10.1111/pbr.12345

Chaikam, V., Molenaar, W., Melchinger, A. E., and Boddupalli, P. M. (2019). Doubled haploid technology for line development in maize: technical advances and prospects. Theor. Appl. Genet. 132, 3227-3243. doi: 10.1007/s00122019-03433-x

Charpentier, E., and Doudna, J. A. (2013). Biotechnology: rewriting a genome. Nature 495, 50-51. doi: 10.1038/495050a

Chen, K., Wang, Y., Zhang, R., Zhang, H., and Gao, C. (2019). CRISPR/Cas genome editing and precision plant breeding in agriculture. Annu. Rev. Plant Biol. 70, 667-697. doi: 10.1146/annurev-arplant-050718-100049

Cho, M.-J., Wu, E., Kwan, J., Yu, M., Banh, J., Linn, W., et al. (2014). Agrobacterium-mediated high-frequency transformation of an elite commercial maize (Zea mays L.) inbred line. Plant Cell Rep. 33, 1767-1777. doi: 10.1007/ s00299-014-1656-x

Coussens, G., Aesaert, S., Verelst, W., Demeulenaere, M., De Buck, S., Njuguna, E., et al. (2012). Brachypodium distachyon promoters as efficient building blocks for transgenic research in maize. J. Exp. Bot. 63, 4263-4273. doi: 10.1093/ jxb/ers113

Cunningham, F. J., Goh, N. S., Demirer, G. S., Matos, J. L., and Landry, M. P. (2018). Nanoparticle-mediated delivery towards advancing plant genetic engineering. Trends Biotechnol. 36, 882-897. doi: 10.1016/j.tibtech.2018.03.009

Debernardi, J. M., Tricoli, D. M., Ercoli, M. F., Hayta, S., Ronald, P., Palatnik, J. F., et al. (2020). A GRF-GIF chimeric protein improves the regeneration efficiency of transgenic plants. Nat. Biotechnol. 38, 1274-1279. doi: 10.1038/ s41587-020-0703-0

Deconinck, K. (2019). New evidence on concentration in seed markets. Glob. Food Sec. 23, 135-138. doi: 10.1016/j.gfs.2019.05.001

Demirer, G. S., Silva, T. N., Jackson, C. T., Thomas, J. B., Ehrhardt, D. W., Rhee, S. Y., et al. (2021). Nanotechnology to advance CRISPR-Cas genetic engineering of plants. Nat. Nanotechnol. 16, 243-250. doi: 10.1038/ s41565-021-00854-y

Demirer, G. S., Zhang, H., Matos, J. L., Goh, N. S., Cunningham, F. J., Sung, Y., et al. (2019). High aspect ratio nanomaterials enable delivery of functional genetic material without DNA integration in mature plants. Nat. Nanotechnol. 14, 456-464. doi: 10.1038/s41565-019-0382-5

Ding, X. S., Schneider, W. L., Chaluvadi, S. R., Mian, M. A. R., and Nelson, R. S. (2006). Characterization of a brome mosaic virus strain and its use as a vector for gene silencing in monocotyledonous hosts. Mol. Plant-Microbe Interact. 19, 1229-1239. doi: 10.1094/MPMI-19-1229

Dong, S., Qin, Y. L., Vakulskas, C. A., Collingwood, M. A., Marand, M., Rigoulot, S., et al. (2021). Efficient targeted mutagenesis mediated by CRISPRCas12a ribonucleoprotein complexes in maize. Front. Genome Edit. 3:13. doi: $10.3389 /$ fgeed.2021.670529

Du, X., Fang, T., Liu, Y., Huang, L., Zang, M., Wang, G., et al. (2019). Transcriptome profiling predicts new genes to promote maize callus formation and transformation. Front. Plant Sci. 10, 1-11. doi: 10.3389/fpls.2019.01633

$\mathrm{Du}, \mathrm{H} ., \mathrm{Wu}, \mathrm{H}$. , Yan, J., and Li, J. (2010). Effects of basal media, salt concentrations, antioxidant supplements and co-effects on the agrobacterium-mediated transformation efficiency in maize. Afr. J. Biotechnol. 9, 1135-1143. doi: 10.5897/ajb09.1276

Eapen, S. (2011). Pollen grains as a target for introduction of foreign genes into plants: An assessment. Physiol. Mol. Biol. Plants 17, 1-8. doi: 10.1007/ s12298-010-0042-6

Eckerstorfer, M. F., Engelhard, M., Heissenberger, A., Simon, S., and Teichmann, H. (2019). Plants developed by new genetic modification techniques-comparison of existing regulatory frameworks in the EU and non-EU countries. Front. Bioeng. Biotechnol. 7:26. doi: 10.3389/fbioe.2019.00026

Eckerstorfer, M. F., Grabowski, M., Lener, M., Engelhard, M., Simon, S., Dolezel, M., et al. (2021). Biosafety of genome editing applications in plant breeding: considerations for a focused case-specific risk assessment in the EU. Biotech 10:10. doi: 10.3390/biotech10030010

Eddy, R., and Hahn, D. T. (2012). Optimizing greenhouse corn production: summary. Purdue methods corn growth. Purdue University Press J. 18, 1-3.

Feys, K., Demuynck, K., De Block, J., Bisht, A., De Vliegher, A., Inzé, D., et al. (2018). Growth rate rather than growth duration drives growth heterosis in maize B104 hybrids. Plant Cell Environ. 41, 374-382. doi: 10.1111/pce.13099

Frame, B. R., Drayton, P. R., Bagnall, S. V., Lewnau, C. J., Bullock, W. P., Wilson, H. M., et al. (1994). Production of fertile transgenic maize plants by silicon carbide whisker-mediated transformation. Plant J. 6, 941-948. doi: 10.1046/j.1365-313X.1994.6060941.x

Frame, B. R., McMurray, J. M., Fonger, T. M., Main, M. L., Taylor, K. W., Torney, F. J., et al. (2006). Improved agrobacterium-mediated transformation of three maize inbred lines using MS salts. Plant Cell Rep. 25, 1024-1034. doi: 10.1007/s00299-006-0145-2

Frame, B. R., Shou, H., Chikwamba, R. K., Zhang, Z., Xiang, C., Fonger, T. M., et al. (2002). Agrobacterium tumefaciens-mediated transformation of maize embryos using a standard binary vector system. Plant Physiol. 129, 13-22. doi: $10.1104 /$ pp.000653

Gao, H., Gadlage, M. J., Lafitte, H. R., Lenderts, B., Yang, M., Schroder, M., et al. (2020a). Superior field performance of waxy corn engineered using CRISPR-Cas9. Nat. Biotechnol. 38, 579-581. doi: 10.1038/s41587-020-0444-0

Gao, H., Mutti, J., Young, J. K., Yang, M., Schroder, M., Lenderts, B., et al. (2020b). Complex trait loci in maize enabled by CRISPR-Cas9 mediated gene insertion. Front. Plant Sci. 11:535. doi: 10.3389/fpls.2020.00535

Gao, Q., Xu, W., Yan, T., Fang, X., Cao, Q., Zhang, Z., et al. (2019). Rescue of a plant cytorhabdovirus as versatile expression platforms for planthopper and cereal genomic studies. New Phytol. 223, 2120-2133. doi: 10.1111/ nph.15889

Geiger, H. H., and Gordillo, G. A. (2009). Doubled haploids in hybrid maize breeding. Maydica 54, 485-499.

Gordon-Kamm, W. J., Spencer, T. M., Mangano, M. L., Adams, T. R., Daines, R. J., Start, W. G., et al. (1990). Transformation of maize cells and regeneration of fertile transgenic plants. Plant Cell 2, 603-618. doi: 10.2307/3869124

Graham, N., Patil, G., Bubeck, D. M., Dobert, R. C., Glenn, K. C., Gutsche, A. T., et al. (2020). Plant genome editing and the relevance of off-target changes. Plant Physiol. 183, 1453-1471. doi: 10.1104/pp.19.01194

Grohmann, L., Keilwagen, J., Duensing, N., Dagand, E., Hartung, F., Wilhelm, R., et al. (2019). Detection and identification of genome editing in plants: challenges and opportunities. Front. Plant Sci. 10:236. doi: 10.3389/ fpls.2019.00236

Häntzschel, K. R., and Weber, G. (2010). Blockage of mitosis in maize root tips using colchicine-alternatives. Protoplasma 241, 99-104. doi: 10.1007/ s00709-009-0103-2

Harfouche, A. L., Petousi, V., Meilan, R., Sweet, J., Twardowski, T., and Altman, A. (2021). Promoting ethically responsible use of agricultural biotechnology. Trends Plant Sci. 26, 546-559. doi: 10.1016/j.tplants.2020.12.015 
He, Y., Zhang, T., Sun, H., Zhan, H., and Zhao, Y. (2020). A reporter for noninvasively monitoring gene expression and plant transformation. Hortic. Res. 7:152. doi: 10.1038/s41438-020-00390-1

Herbert, L., Meunier, A.-C., Bes, M., Vernet, A., Portefaix, M., Durandet, F., et al. (2020). Beyond seek and destroy: how to generate allelic series using genome editing tools. Rice 13, 1-9. doi: 10.1186/s12284-020-0366-y

Hoekema, A., Hirsch, P. R., Hooykaas, P. J. J., and Schilperoort, R. A. (1983). A binary plant vector strategy based on separation of vir- and T-region of the agrobacterium tumefaciens Ti-plasmid. Nature 303, 179-180. doi: $10.1038 / 303179 \mathrm{a} 0$

Hoerster, G., Wang, N., Ryan, L., Wu, E., Anand, A., McBride, K., et al. (2020). Use of non-integrating $\mathrm{Zm}$-Wus2 vectors to enhance maize transformation: non-integrating WUS2 enhances transformation. Vitr. Cell. Dev. Biol. - Plant 56, 265-279. doi: 10.1007/s11627-019-10042-2

Holme, I. B., Wendt, T., and Holm, P. B. (2013). Intragenesis and cisgenesis as alternatives to transgenic crop development. Plant Biotechnol. J. 11, 395-407. doi: 10.1111/pbi.12055

Hood, E. E., Helmer, G. L., Fraley, R. T., and Chilton, M. D. (1986). The hypervirulence of agrobacterium tumefaciens A281 is encoded in a region of pTiBo542 outside of T-DNA. J. Bacteriol. 168, 1291-1301. doi: 10.1128/ jb.168.3.1291-1301.1986

Howard, P. (2009). Visualizing consolidation in the global seed industry: 1996-2008. Sustain. For. 1, 1266-1287. doi: 10.3390/su1041266

Hu, J., Li, S., Li, Z., Li, H., Song, W., Zhao, H., et al. (2019). A barley stripe mosaic virus-based guide RNA delivery system for targeted mutagenesis in wheat and maize. Mol. Plant Pathol. 20, 1463-1474. doi: 10.1111/mpp.12849

Huang, X., and Wei, Z. (2005). Successful agrobacterium-mediated genetic transformation of maize elite inbred lines. Plant Cell Tissue Organ Cult. 83, 187-200. doi: 10.1007/s11240-005-5772-8

Hufford, M. B., Seetharam, A. S., Woodhouse, M. R., Chougule, K. M., Ou, S., Liu, J., et al. (2021). De novo assembly, annotation, and comparative analysis of 26 diverse maize genomes. Science 373, 655-662. doi: 10.1126/science. abg5289

Hull, R., Head, G., and Tzotzos, G. T. (eds.) (2021). "Evolution of regulatory systems and national biosafety frameworks," in Genetically Modified Plants. 2nd Edn. (Cambridge, Massachusetts, EUA: Elsevier), 127-155.

Hwang, E. E., Wang, M. B., Bravo, J. E., and Banta, L. M. (2015). Unmasking host and microbial strategies in the agrobacterium-plant defense tango. Front. Plant Sci. 6, 1-17. doi: 10.3389/fpls.2015.00200

ISAAA Brief (2019). Global Status of Commercialized Biotech/GM Crops in 2019. ISAAA Ithaca: NY

ISAAA database (2021). GM Approval Database. Available at: https://www. isaaa.org/gmapprovaldatabase/default.asp (Accessed August 10, 2021).

Ishida, Y., Hiei, Y., and Komari, T. (2007). Agrobacterium-mediated transformation of maize. Nat. Protoc. 2, 1614-1621. doi: 10.1038/nprot.2007.241

Ishida, Y., Hiei, Y., and Komari, T. (2020). Tissue culture protocols for gene transfer and editing in maize (Zea mays L.). Plant Biotechnol. 37, 121-128. doi: 10.5511/plantbiotechnology.20.0113a

Ishida, Y., Saito, H., Hiei, Y., and Komari, T. (2003). Improved protocol for transformation of maize (Zea mays L.) mediated by agrobacterium tumefaciens. Plant Biotechnol. 20, 57-66. doi: 10.5511/plantbiotechnology.20.57

Ishida, Y., Saito, H., Ohta, S., Hiei, Y., Komari, T., and Kumashiro, T. (1996). High efficiency transformation of maize (Zea Mays L.) mediated by agrobacterium tumefaciens. Nat. Biotechnol. 14, 745-750. doi: 10.1038/ nbt0696-745

Jacquier, N. M. A., Gilles, L. M., Martinant, J.-P., Rogowsky, P. M., and Widiez, T. (2021). Maize In planta haploid inducer lines: A cornerstone for doubled haploid technology. Methods Mol. Biol. 2288, 25-48. doi: 10.1007/9781-0716-1335-1_2

Jacquier, N. M. A., Gilles, L. M., Pyott, D. E., Martinant, J.-P., Rogowsky, P. M., and Widiez, T. (2020). Puzzling out plant reproduction by haploid induction for innovations in plant breeding. Nat. plants 6, 610-619. doi: 10.1038/ s41477-020-0664-9

Jarugula, S., Willie, K., and Stewart, L. R. (2018). Barley stripe mosaic virus (BSMV) as a virus-induced gene silencing vector in maize seedlings. Virus Genes 54, 616-620. doi: 10.1007/s11262-018-1569-9

Jorasch, P. (2020). Potential, challenges, and threats for the application of new breeding techniques by the private plant breeding sector in the EU. Front. Plant Sci. 11:1463. doi: 10.3389/fpls.2020.582011
Jupe, F., Rivkin, A. C., Michael, T. P., Zander, M., Motley, S. T., Sandoval, J. P., et al. (2019). The complex architecture and epigenomic impact of plant T-DNA insertions. PLoS Genet. 15:e1007819. doi: 10.1371/journal.pgen.1007819

Kausch, A. P., Nelson-Vasilchik, K., Tilelli, M., and Hague, J. P. (2021a). Maize tissue culture, transformation, and genome editing. Vitr. Cell. Dev. Biol. Plant. 2, 1-9. doi: 10.1007/s11627-021-10196-y

Kausch, A. P., Wang, K., Kaeppler, H. F., and Gordon-Kamm, W. (2021b). Maize transformation: history, progress, and perspectives. Mol. Breed. 41:38. doi: $10.1007 / \mathrm{s} 11032-021-01225-0$

Kelliher, T., Starr, D., Richbourg, L., Chintamanani, S., Delzer, B., Nuccio, M. L., et al. (2017). MATRILINEAL, a sperm-specific phospholipase, triggers maize haploid induction. Nature 542, 105-109. doi: 10.1038/nature20827

Kelliher, T., Starr, D., Su, X., Tang, G., Chen, Z., Carter, J., et al. (2019). Onestep genome editing of elite crop germplasm during haploid induction. Nat. Biotechnol. 37, 287-292. doi: 10.1038/s41587-019-0038-x

Kim, S. R., and An, G. (2012). Bacterial transposons are co-transferred with T-DNA to rice chromosomes during agrobacterium-mediated transformation. Mol. Cell 33, 583-589. doi: 10.1007/s10059-012-0010-9

Komari, T., Takakura, Y., Ueki, J., Kato, N., Ishida, Y., and Hiei, Y. (2006). "Binary vectors and super-binary vectors," Agrobacterium Protocols. in Methods in Molecular Biology. ed. K. Wang (Clifton, New Jersey: Humana Press), 15-41.

Kong, J., Martin-Ortigosa, S., Finer, J., Orchard, N., Gunadi, A., Batts, L. A., et al. (2020). Overexpression of the transcription factor GROWTHREGULATING FACTOR5 improves transformation of dicot and monocot species. Front. Plant Sci. 11, 1-15. doi: 10.3389/fpls.2020.572319

Lassoued, R., Phillips, P. W. B., Smyth, S. J., and Hesseln, H. (2019). Estimating the cost of regulating genome edited crops: expert judgment and overconfidence. GM Crop. Food 10, 44-62. doi: 10.1080/21645698.2019.1612689

Lee, H., and Zhang, Z. J. (2016). Maize (Zea mays) hi-II transformation via agrobacterium-mediated T-DNA transfer. Curr. Protoc. Plant Biol. 1, 121-137. doi: $10.1002 / \mathrm{cppb} .20016$

Li, C., Liu, C., Qi, X., Wu, Y., Fei, X., Mao, L., et al. (2017). RNA-guided Cas9 as an in vivo desired-target mutator in maize. Plant Biotechnol. J. 15, 1566-1576. doi: 10.1111/pbi.12739

Li, J. F., Norville, J. E., Aach, J., McCormack, M., Zhang, D., Bush, J., et al. (2013). Multiplex and homologous recombination-mediated genome editing in Arabidopsis and Nicotiana benthamiana using guide RNA and Cas9. Nat. Biotechnol. 31, 688-691. doi: 10.1038/nbt.2654

Liu, H.-J., Jian, L., Xu, J., Zhang, Q., Zhang, M., Jin, M., et al. (2020). Highthroughput CRISPR/Cas9 mutagenesis streamlines trait gene identification in maize. Plant Cell 32, 1397-1413. doi: 10.1105/tpc.19.00934

Lowe, K., La Rota, M., Hoerster, G., Hastings, C., Wang, N., Chamberlin, M., et al. (2018). Rapid genotype "independent" Zea mays L. (maize) transformation via direct somatic embryogenesis. Vitr. Cell. Dev. Biol. - Plant 54, 240-252. doi: 10.1007/s11627-018-9905-2

Lowe, K., Wu, E., Wang, N., Hoerster, G., Hastings, C., Cho, M.-J., et al. (2016). Morphogenic regulators Baby boom and Wuschel improve monocot transformation. Plant Cell 28, 1998-2015. doi: 10.1105/tpc.16.00124

Masters, A., Kang, M., McCaw, M., Zobrist, J. D., Gordon-Kamm, W., Jones, T., et al. (2020). Agrobacterium-mediated immature embryo transformation of recalcitrant maize inbred lines using morphogenic genes. J. Vis. Exp. 2020, 1-11. doi: $10.3791 / 60782$

Mcdougall, P. (2011). The cost and time involved in the discovery, development and authorisation of a new plant biotechnology derived trait A consultancy study for crop life international September 2011. Vineyard Bus. Cent., 1-24.

Mei, Y., Beernink, B. M., Ellison, E. E., Konečná, E., Neelakandan, A. K. Voytas, D. F., et al. (2019). Protein expression and gene editing in monocots using foxtail mosaic virus vectors. Plant Direct. 3:e00181. doi: 10.1002/ pld3.181

Melchinger, A. E., Molenaar, W. S., Mirdita, V., and Schipprack, W. (2016). Colchicine alternatives for chromosome doubling in maize haploids for doubled-haploid production. Crop Sci. 56, 559-569. doi: 10.2135/ cropsci2015.06.0383

Melchinger, A. E., Schipprack, W., Würschum, T., Chen, S., and Technow, F. (2013). Rapid and accurate identification of in vivo-induced haploid seeds based on oil content in maize. Sci. Rep. 3:2129. doi: 10.1038/srep02129

Michael, T. P., and VanBuren, R. (2015). Progress, challenges and the future of crop genomes. Curr. Opin. Plant Biol. 24, 71-81. doi: 10.1016/j.pbi.2015.02.002 
Moar, W., Khajuria, C., Pleau, M., Ilagan, O., Chen, M., Jiang, C., et al. (2017). Cry3Bb1-resistant western corn rootworm, diabrotica virgifera virgifera (LeConte) does not exhibit cross-resistance to DvSnf7 dsRNA. PLoS One 12, 1-15. doi: 10.1371/journal.pone.0169175

Mookkan, M., Nelson-Vasilchik, K., Hague, J., Zhang, Z. J., and Kausch, A. P. (2017). Selectable marker independent transformation of recalcitrant maize inbred B73 and sorghum $\mathrm{P} 898012$ mediated by morphogenic regulators BABY BOOM and WUSCHEL2. Plant Cell Rep. 36, 1477-1491. doi: 10.1007/ s00299-017-2169-1

Mu, G., Chang, N., Xiang, K., Sheng, Y., Zhang, Z., and Pan, G. (2012). Genetic transformation of maize female inflorescence following floral dip method mediated by agrobacterium. Biotechnology 11, 178-183. doi: 10.3923/ biotech.2012.178.183

Mumm, R. H. (2013). A look at product development with genetically modified crops: examples from maize. J. Agric. Food Chem. 61, 8254-8259. doi: $10.1021 /$ jf400685y

National Academies of Sciences, Engineering, and Medicine. (2016). Genetically Engineered Crops: Experiences and Prospects. Washington, DC: The National Academies Press.

Nekrasov, V., Staskawicz, B., Weigel, D., Jones, J. D. G., and Kamoun, S. (2013). Targeted mutagenesis in the model plant Nicotiana benthamiana using Cas 9 RNA-guided endonuclease. Nat. Biotechnol. 31, 691-693. doi: 10.1038/nbt.2655

Nonaka, S., Someya, T., Kadota, Y., Nakamura, K., and Ezura, H. (2019). Superagrobacterium ver. 4: improving the transformation frequencies and genetic engineering possibilities for crop plants. Front. Plant Sci. 10:1204. doi: 10.3389/fpls.2019.01204

Nuccio, M. L., Paul, M., Bate, N. J., Cohn, J., and Cutler, S. R. (2018). Where are the drought tolerant crops?, An assessment of more than two decades of plant biotechnology effort in crop improvement. Plant Sci. 273, 110-119. doi: $10.1016 /$ j.plantsci.2018.01.020

Omer, R. A., Matheka, J. M., Abdelbagi, A. M., and Machuka, J. (2013). Transformation of tropical maize with the NPK1 gene for drought tolerance. Int. J. Genet. Eng. 3, 7-14. doi: 10.5923/j.ijge.20130302.01

Pellegrino, E., Bedini, S., Nuti, M., and Ercoli, L. (2018). Impact of genetically engineered maize on agronomic, environmental and toxicological traits: a metaanalysis of 21 years of field data. Sci. Rep. 8:3113. doi: 10.1038/s41598-018-21284-2

Peng, T., Sun, X., and Mumm, R. H. (2014). Optimized breeding strategies for multiple trait integration: I. minimizing linkage drag in single event introgression. Mol. Breed. 33, 89-104. doi: 10.1007/s11032-013-9936-7

Pitzschke, A. (2013). Agrobacterium infection and plant defense-transformation success hangs by a thread. Front. Plant Sci. 4:519. doi: 10.3389/fpls.2013.00519

Portwood, J. L., Woodhouse, M. R., Cannon, E. K., Gardiner, J. M., Harper, L. C., Schaeffer, M. L., et al. (2019). MaizeGDB 2018: the maize multi-genome genetics and genomics database. Nucleic Acids Res. 47, D1146-D1154. doi: 10.1093/nar/gky1046

Prado, J. R., Segers, G., Voelker, T., Carson, D., Dobert, R., Phillips, J., et al. (2014). Genetically engineered crops: From idea to product. Annu. Rev. Plant Biol. 65, 769-790. doi: 10.1146/annurev-arplant-050213-040039

Prasanna, B. M., Vijay, C., and George, M. (2012). Doubled Haploid Technology in Maize Breeding: Theory and Practice Cimmyt. (CYMMIT, Mexico), 1-56.

Qi, X., Wu, H., Jiang, H., Zhu, J., Huang, C., Zhang, X., et al. (2020). Conversion of a normal maize hybrid into a waxy version using in vivo CRISPR/Cas9 targeted mutation activity. Crop J. 8, 440-448. doi: 10.1016/j.cj.2020.01.006

Que, Q., Elumalai, S., Li, X., Zhong, H., Nalapalli, S., Schweiner, M., et al. (2014). Maize transformation technology development for commercial event generation. Front. Plant Sci. 5:379. doi: 10.3389/fpls.2014.00379

Raji, J. A., Frame, B., Little, D., Santoso, T. J., and Wang, K. (2018). “Agrobacteriumand biolistic-mediated transformation of maize B104 inbred," in Maize. Methods in Molecular Biology. Vol. 1676. ed. L. M. Lagrimini (New York: Humana Press), 15-40.

Rodrigues, S. D., Karimi, M., Impens, L., van Lerberge, E., Coussens, G., Aesaert, S., et al. (2021). Efficient CRISPR-mediated base editing in agrobacterium spp. Proc. Natl. Acad. Sci. U. S. A. 118:e2013338118. doi: 10.1073/pnas.2013338118

Sardesai, N., Foulk, S., Chen, W., Wu, H., Etchison, E., and Gupta, M. (2018). Coexpression of octopine and succinamopine agrobacterium virulence genes to generate high quality transgenic events in maize by reducing vector backbone integration. Transgenic Res. 27, 539-550. doi: 10.1007/s11248-018-0097-7

Sardesai, N., Lee, L. Y., Chen, H., Yi, H., Olbricht, G. R., Stirnberg, A., et al. (2013). Cytokinins secreted by agrobacterium promote transformation by repressing a plant myb transcription factor. Sci. Signal. 6:re100. doi: 10.1126/ scisignal.2004518

Schaart, J. G., van de Wiel, C. C. M., Lotz, L. A. P., and Smulders, M. J. M. (2016). Opportunities for products of new plant breeding techniques. Trends Plant Sci. 21, 438-449. doi: 10.1016/j.tplants.2015.11.006

Schellenberger, U., Oral, J., Rosen, B. A., Wei, J. Z., Zhu, G., Xie, W., et al. (2016). A selective insecticidal protein from pseudomonas for controlling corn rootworms. Science 354, 634-637. doi: 10.1126/science.aaf6056

Schiemann, J., DIetz-Pfeilstetter, A., Hartung, F., Kohl, C., Romeis, J., and Sprink, T. (2019). Risk assessment and regulation of plants modified by modern biotechniques: current status and future challenges. Annu. Rev. Plant Biol. 70, 699-726. doi: 10.1146/annurev-arplant-050718-100025

Shan, Q., Wang, Y., Li, J., Zhang, Y., Chen, K., Liang, Z., et al. (2013). Targeted genome modification of crop plants using a CRISPR-Cas system. Nat. Biotechnol. 31, 686-688. doi: 10.1038/nbt.2650

Shi, J., Gao, H., Wang, H., Lafitte, H. R., Archibald, R. L., Yang, M., et al. (2017). ARGOS8 variants generated by CRISPR-Cas9 improve maize grain yield under field drought stress conditions. Plant Biotechnol. J. 15, 207-216. doi: $10.1111 /$ pbi.12603

Shi, J., Habben, J. E., Archibald, R. L., Drummond, B. J., Chamberlin, M. A., Williams, R. W., et al. (2015). Overexpression of ARGOS genes modifies plant sensitivity to ethylene, leading to improved drought tolerance in Both Arabidopsis and maize. Plant Physiol. 169, 266-282. doi: 10.1104/pp.15.00780

Simmons, C. R., Lafitte, H. R., Reimann, K. S., Brugière, N., Roesler, K., Albertsen, M. C., et al. (2021). Successes and insights of an industry biotech program to enhance maize agronomic traits. Plant Sci. 307:110899. doi: 10.1016/j.plantsci.2021.110899

Simmons, C. R., Weers, B. P., Reimann, K. S., Abbitt, S. E., Frank, M. J., Wang, W., et al. (2020). Maize BIG GRAIN1 homolog overexpression increases maize GRAIN yield. Plant Biotechnol. J. 18, 2304-2315. doi: 10.1111/pbi.13392

Strable, J., and Scanlon, M. J. (2009). Maize (Zea mays): A Model Organism for Basic and Applied Research in Plant Biology. Cold Spring Harb. Protoc. 2009:emo132. doi: 10.1101/pdb.emo132

Svitashev, S., Schwartz, C., Lenderts, B., Young, J. K., and Mark Cigan, A. (2016). Genome editing in maize directed by CRISPR-Cas9 ribonucleoprotein complexes. Nat. Commun. 7:13274. doi: 10.1038/ncomms13274

Svitashev, S., Young, J. K., Schwartz, C., Gao, H., Falco, S. C., and Cigan, A. M. (2015). Targeted mutagenesis, precise gene editing, and site-specific gene insertion in maize using Cas9 and guide RNA. Plant Physiol. 169, 931-945. doi: $10.1104 /$ pp.15.00793

Tabashnik, B. E., and Carrière, Y. (2017). Surge in insect resistance to transgenic crops and prospects for sustainability. Nat. Biotechnol. 35, 926-935. doi: 10.1038/nbt.3974

Torti, S., Schlesier, R., Thümmler, A., Bartels, D., Römer, P., Koch, B., et al. (2021). Transient reprogramming of crop plants for agronomic performance. Nat. Plants 7, 159-171. doi: 10.1038/s41477-021-00851-y

Trentin, H. U., Frei, U. K., and Lübberstedt, T. (2020). Breeding maize maternal haploid inducers. Plan. Theory 9:614. doi: 10.3390/plants9050614

Turnbull, C., Lillemo, M., and Hvoslef-Eide, T. A. K. (2021). Global regulation of genetically modified crops Amid the gene edited crop boom - A review. Front. Plant Sci. 12:630396. doi: 10.3389/fpls.2021.630396

Ülker, B., Li, Y., Rosso, M. G., Logemann, E., Somssich, I. E., and Weisshaar, B. (2008). T-DNA-mediated transfer of agrobacterium tumefaciens chromosomal DNA into plants. Nat. Biotechnol. 26, 1015-1017. doi: 10.1038/nbt.1491

USDA-APHIS (2021). Regul. Artic. Lett. Inq. Website. Available at: https:// www.aphis.usda.gov/aphis/ourfocus/biotechnology/am-i-regulated/regulated_ article_letters_of_inquiry/regulated_article_letters_of_inquiry (Accessed August 11, 2021).

Vaghchhipawala, Z., Radke, S., Nagy, E., Russell, M. L., Johnson, S., Gelvin, S. B., et al. (2018). RepB C-terminus mutation of a pRi-repABC binary vector affects plasmid copy number in agrobacterium and transgene copy number in plants. PLoS One 13:e0200972. doi: 10.1371/journal.pone.0200972

van de Wiel, C. C. M., Schaart, J. G., Lotz, L. A. P., and Smulders, M. J. M. (2017). New traits in crops produced by genome editing techniques based on deletions. Plant Biotechnol. Rep. 11, 1-8. doi: 10.1007/s11816-017-0425-Z

Van Der Fits, L., Deakin, E. A., Hoge, J. H. C., and Memelink, J. (2000). The ternary transformation system: constitutive virG on a compatible plasmid dramatically increases agrobacterium-mediated plant transformation. Plant Mol. Biol. 43, 495-502. doi: 10.1023/A:1006440221718 
Van Tassel, D. L., Tesdell, O., Schlautman, B., Rubin, M. J., DeHaan, L. R., Crews, T. E., et al. (2020). New food crop domestication in the age of gene editing: genetic, agronomic and cultural change remain co-evolutionarily entangled. Front. Plant Sci. 11:789. doi: 10.3389/fpls.2020.00789

Vega, J. M., Yu, W., Kennon, A. R., Chen, X., and Zhang, Z. J. (2008). Improvement of agrobacterium-mediated transformation in hi-II maize (Zea mays) using standard binary vectors. Plant Cell Rep. 27, 297-305. doi: 10.1007/s00299-007-0463-Z

Vejlupkova, Z., Warman, C., Sharma, R., Scheller, H. V., Mortimer, J. C., and Fowler, J. E. (2020). No evidence for transient transformation via pollen magnetofection in several monocot species. Nat. Plants 6, 1323-1324. doi: 10.1038/s41477-020-00798-6

Wan, X., Wu, S., Li, Z., Dong, Z., An, X., Ma, B., et al. (2019). Maize genic male-sterility genes and their applications in hybrid breeding: Progress and perspectives. Mol. Plant 12, 321-342. doi: 10.1016/j.molp.2019.01.014

Wang, K., Frame, B., Ishida, Y., and Komari, T. (2009). "Maize transformation," in Handbook of Maize. eds. J. L. Bennetzen and S. Hake (New York, NY: Springer New York), 609-639.

Wang, R., Yang, X., Wang, N., Liu, X., Nelson, R. S., Li, W., et al. (2016). An efficient virus-induced gene silencing vector for maize functional genomics research. Plant J. 86, 102-115. doi: 10.1111/tpj.13142

Wang, Y., Zhang, S., Huang, F., Zhou, X., Chen, Z., Peng, W., et al. (2018). VirD5 is required for efficient agrobacterium infection and interacts with Arabidopsis VIP2. New Phytol. 217, 726-738. doi: 10.1111/nph.14854

Wang, B., Zhu, L., Zhao, B., Zhao, Y., Xie, Y., Zheng, Z., et al. (2019). Development of a haploid-inducer mediated genome editing system for accelerating maize breeding. Mol. Plant 12, 597-602. doi: 10.1016/j.molp.2019.03.006

Woźniak, E., Tyczewska, A., and Twardowski, T. (2021). A shift towards biotechnology: social opinion in the EU. Trends Biotechnol. 39, 214-218. doi: 10.1016/j.tibtech.2020.08.001

Wu, J., Lawit, S. J., Weers, B., Sun, J., Mongar, N., Van Hemert, J., et al. (2019). Overexpression of $\mathrm{zmm} 28$ increases maize grain yield in the field. Proc. Natl. Acad. Sci. 116, 23850-23858. doi: 10.1073/pnas.1902593116

Xie, W., Marty, D. M., Xu, J., Khatri, N., Willie, K., Moraes, W. B., et al. (2021). Simultaneous gene expression and multi-gene silencing in Zea mays using maize dwarf mosaic virus. BMC Plant Biol. 21:208. doi: 10.1186/ s12870-021-02971-1

Xu, J., Yin, Y., Jian, L., Han, B., Chen, Z., Yan, J., et al. (2021). Seeing is believing: a visualization toolbox to enhance selection efficiency in maize genome editing. Plant Biotechnol. J. 19, 872-874. doi: 10.1111/pbi.13575

Yadava, P., Abhishek, A., Singh, R., Singh, I., Kaul, T., Pattanayak, A., et al. (2017). Advances in maize transformation technologies and development of transgenic maize. Front. Plant Sci. 7:1949. doi: 10.3389/fpls.2016.01949

Yan, Y., Zhu, J., Qi, X., Cheng, B., Liu, C., and Xie, C. (2021). Establishment of an efficient seed fluorescence reporter-assisted CRISPR/Cas9 gene editing in maize. J. Integr. Plant Biol. 63, 1671-1680. doi: 10.1111/jipb.13086

Yang, L., Cui, G., Wang, Y., Hao, Y., Du, J., Zhang, H., et al. (2017). Expression of foreign genes demonstrates the effectiveness of pollen-mediated transformation in Zea mays. Front. Plant Sci. 8:383. doi: 10.3389/fpls.2017.00383

Ye, X., Williams, E. J., Shen, J., Johnson, S., Lowe, B., Radke, S., et al. (2011). Enhanced production of single copy backbone-free transgenic plants in multiple crop species using binary vectors with a $\mathrm{pRi}$ replication origin in agrobacterium tumefaciens. Transgenic Res. 20, 773-786. doi: 10.1007/ s11248-010-9458-6

Yin, Y., Flasinski, S., Moar, W., Bowen, D., Chay, C., Milligan, J., et al. (2020). A new bacillus thuringiensis protein for Western corn rootworm control. PLoS One 15, 1-16. doi: 10.1371/journal.pone.0242791

Young, J., Zastrow-Hayes, G., Deschamps, S., Svitashev, S., Zaremba, M., Acharya, A., et al. (2019). CRISPR-Cas9 editing in maize: systematic evaluation of off-target activity and its relevance in crop improvement. Sci. Rep. 9:6729. doi: 10.1038/s41598-019-43141-6

Yu, W., and Birchler, J. A. (2016). A green fluorescent protein-engineered haploid inducer line facilitates haploid mutant screens and doubled haploid breeding in maize. Mol. Breed. 36, 1-12. doi: 10.1007/s11032-015-0428-9

Zaidi, S. S.-A., and Mansoor, S. (2017). Viral vectors for plant genome engineering. Front. Plant Sci. 8:539. doi: 10.3389/fpls.2017.00539

Zambryski, P., Depicker, A., Kruger, K., and Goodman, H. M. (1982). Tumor induction by agrobacterium tumefaciens: analysis of the boundaries of T-DNA J. Mol. Appl. Genet. 1, 361-370. doi: 10.3389/fpls.2017.00539

Zhang, Y., Pribil, M., Palmgren, M., and Gao, C. (2020a). A CRISPR way for accelerating improvement of food crops. Nat. Food 1, 200-205. doi: 10.1038/ s43016-020-0051-8

Zhang, Y., Yin, X., Yang, A., Li, G., and Zhang, J. (2005). Stability of inheritance of transgenes in maize (Zea mays L.) lines produced using different transformation methods. Euphytica 144, 11-22. doi: 10.1007/s10681-005-4560-1

Zhang, J., Zhang, X., Chen, R., Yang, L., Fan, K., Liu, Y., et al. (2020b). Generation of transgene-free Semidwarf maize plants by gene editing of gibberellin-Oxidase20-3 using CRISPR/Cas9. Front. Plant Sci. 11:1048. doi: $10.3389 /$ fpls. 2020.01048

Zhang, Q., Zhang, Y., Lu, M.-H., Chai, Y.-P., Jiang, Y.-Y., Zhou, Y., et al. (2019). A novel ternary vector system united with Morphogenic genes enhances CRISPR/Cas delivery in maize. Plant Physiol. 181, 1441-1448. doi: 10.1104/ pp.19.00767

Zhao, Z. Y., Gu, W., Cai, T., Tagliani, L., Hondred, D., Bond, D., et al. (2002). High throughput genetic transformation mediated by agrobacterium tumefaciens in maize. Mol. Breed. 8, 323-333. doi: 10.1023/A:1015243600325

Zhong, H., Elumalai, S., Nalapalli, S., Richbourg, L., Prairie, A., Bradley, D., et al. (2018). "Advances in agrobacterium-mediated maize transformation," in Methods in Molecular Biology. ed. L. M. Lagrimini (New York: Humana Press), 41-59.

Zhong, Y., Liu, C., Qi, X., Jiao, Y., Wang, D., Wang, Y., et al. (2019). Mutation of ZmDMP enhances haploid induction in maize. Nat. Plants 5, 575-580. doi: 10.1038/s41477-019-0443-7

Zhou, W., Jia, C. G., Wu, X., Hu, R. X., Yu, G., Zhang, X. H., et al. (2016). ZmDBF3, a novel transcription factor from maize (Zea mays L.), is involved in multiple abiotic stress tolerance. Plant Mol. Biol. Report. 34, 353-364. doi: 10.1007/s11105-015-0926-2

Zhou, L. Z., Juranić, M., and Dresselhaus, T. (2017). Germline development and fertilization mechanisms in maize. Mol. Plant 10, 389-401. doi: 10.1016/j. molp.2017.01.012

Conflict of Interest: The authors declare that the research was conducted in the absence of any commercial or financial relationships that could be construed as a potential conflict of interest.

Publisher's Note: All claims expressed in this article are solely those of the authors and do not necessarily represent those of their affiliated organizations, or those of the publisher, the editors and the reviewers. Any product that may be evaluated in this article, or claim that may be made by its manufacturer, is not guaranteed or endorsed by the publisher.

Copyright (c) 2021 Yassitepe, da Silva, Hernandes-Lopes, Dante, Gerhardt, Fernandes, Da Silva, Vieira, Bonatti and Arruda. This is an open-access article distributed under the terms of the Creative Commons Attribution License (CC BY). The use, distribution or reproduction in other forums is permitted, provided the original author(s) and the copyright owner(s) are credited and that the original publication in this journal is cited, in accordance with accepted academic practice. No use, distribution or reproduction is permitted which does not comply with these terms. 